\title{
STRUCTURAL CHANGE AND THE INCOME OF NATIONS
}

Cynthia Armas

Fernando Sánchez-Losada 
Title: Structural change and the income of nations

\begin{abstract}
An increase in the supply of skilled labor has been common across the world. However, despite the rise in skilled labor force, not all countries have achieved high income levels, even when their structural transformation follows the same path (from agriculture to industry and, then, from industry to services). Skilled workers might end up in either high or low TFP sectors, according to two opposite theories of structural change (skill-biased structural transformation and stagnant structural transformation). We show that directed technical change is needed to achieve skill-biased structural transformation and, therefore, skilled workers are allocated to high TFP sectors. We present macrodata and microdata evidence to identify the existence of directed technical change. We reveal that in the U.S., South Korea and France, skilled workers have ended up in high TFP sectors due to the existence of directed technical change in the process of structural transformation, but not in Canada. There is a lack of clear evidence for Italy and Spain.
\end{abstract}

JEL Codes: J24, O14

Keywords: Structural change, directed technical change, unskilled and skilled sectors

\title{
Authors:
}

Cynthia Armas

Universitat de Barcelona

Email: cyarmasr7@alumnes.ub.edu
Fernando Sánchez-Losada

Universitat de Barcelona

Email: fernando.sanchezlosada@ub.edu

Date: May 2021

Acknowledgements: Fernando Sánchez-Losada acknowledges the financial support from the Ministerio de Economía y Competitividad and Fondo Europeo de Desarrollo Regional through grant RTI2018-093543-B-I00 (MINECO/FEDER, UE). Cynthia Armas acknowledges the financial support from the APIF fellowship. 


\section{Introduction}

An increase in tertiary educated labor force — skilled workers - is common across countries. According to the OECD, on average, $20.25 \%$ of the population had completed tertiary education in 1998 and rose to $36.91 \%$ in 2017. In the U.S., $19.11 \%$ of the population aged 25 and over had completed tertiary education in 1981 while in 2017 this number increased to $46.36 \%^{1}$. This increase in skilled labor supply has induced a change in the composition of the labor force in the U.S. In 2000, 31.36\% of employees aged 25 and over were high school graduates and $31.11 \%$ had a bachelor's degree or higher, while in 2017 the proportion of high school graduates dropped to $24.95 \%$ and college graduates increased to $42.26 \%$. Moreover, the wage gap between employees who hold a bachelor's degree or higher and high school graduates increased from $41.35 \%$ in 1980 to $79.63 \%$ in $2017^{2}$.

Technological change theories such as directed technical change explain this increase in skill premium. Acemoglu $(1998,2002)$ argues that when skilled and unskilled workers are weak substitutes then, if the market size effect dominates the price effect ${ }^{3}$, technical change is directed towards the more abundant factor, which increases the productivity of skilled workers. Profit maximizing firms decide to invest in skill-complementary technology due to an increase in relative skilled labor supply. Thus, an increase in human capital induces a skill-biased structural change if there is directed technical change and, then, structural transformation follows a path in which skilled workers are allocated to high TFP sectors. Buera et al. (2018) describe skill-biased structural change as the reallocation of sector value added shares towards high-skill intensive industries, causing an increase in skill premium.

\footnotetext{
${ }^{1}$ Source: OECD.

2 Source: U.S. Bureau of Labor Statistics.

${ }^{3}$ The price effect consists of a reduction in relative skilled wage caused directly by this increase in relative skilled labor supply. The market size effect consists of an increase in relative skilled wage caused by the increase of relative skilled productivity when profit maximizing firms decide to invest in skill-complementary technology due to an increase in relative skilled labor supply.
} 
There is another path for structural transformation. In this path, skilled workers are likely to end up in low TFP sectors. Baumol (1967) claimed that if the proportion of output remains between a stagnant sector (with constant labor productivity) and a progressive sector (with increasing labor productivity), production costs and prices would tend to rise in the stagnant sector and, therefore, the labor force would move from high TFP growth to low TFP growth sectors.

These opposite paths — stagnant sector structural change and skill-biased structural change - suggest that an increase in skilled workers does not determine by itself whether the economy will achieve high income levels during structural transformation (hereafter, an economy with high income levels is one that is converging with the U.S.; economies are considered to have low income levels otherwise). This paper shows that an increase in human capital has to exist along with directed technical change for an economy to end up in high income levels. We provide macrodata and microdata evidence that helps us to ascertain whether an economy has experienced directed technical change during its structural transformation. The macrodata evidence considers six economic sectors ${ }^{4}$ and the existence of directed technical change is identified through an analysis of the relative TFP of skilled versus unskilled sectors and the relative factors used in the production process. The increase in relative skilled TFP suggests the existence of directed technical change because profit maximizing firms develop skill-complementary technologies due to the increase of skilled labor force, which leads to a rise in relative skilled productivity increase. The microdata evidence identifies the existence of directed technical change through the analysis of a GLS estimation of wages as a function of variables, such as workers' education level and economic sector. The highest value and significance of the coefficient of the interaction term between workers' education level and a high TFP economic sector point to the existence of directed technical change.

\footnotetext{
${ }^{4}$ Agriculture, Low-Tech Industry, High-Tech Industry, Unskilled Services, Skilled Market Services, and Skilled Non-Market Services.
} 
The paper is organized as follows. Section 2 describes the literature. Section 3 shows how the existence of directed technical change can be identified through an analysis of relative skilled TFP. Section 4 presents a GLS panel data estimation for various countries and identifies the existence of directed technical change when the coefficient of the interaction term between the level of education and a high TFP economic sector is the highest and significant. Finally, Section 5 concludes.

\section{Literature}

Our paper builds on a rich and diverse literature on structural change, a phenomenon observed in the process of growth. The literature generally states that less productive workers are replaced by machines and allocated to other sectors. Thus, less productive workers are allocated first from agriculture to industry and, then, from industry to services. Because of this technological process and reallocation of the labor force, agriculture and industry tend to be the economy's most productive sectors and services tend to be the least productive sector. However, productivity in the services sector varies from one country to another. In high income countries, such as the U.S., labor productivity in services is higher than in low income countries. Moreover, low income countries show low productivity rates not only in the services sector, but in all sectors; see Timmer and de Vries (2009), Duarte and Restuccia (2010), García-Santana et al. (2016) and Święcki (2017). From a demand perspective, structural transformation occurs because of changes in aggregate demand structure. The consumption of goods relative to services differs between rich and poor households; see Boppart (2014). Most of the literature on structural transformation uses consumer non-homothetic preferences to explain the shift in consumption from agricultural goods to industrial goods and, successively, to services; see Comin et al. (2015). In view of the international evidence shown in all these papers, it seems that structural transformation, by itself, is not a guarantee for a country to achieve a high income per capita. 
Jorgenson and Timmer (2011), Barany and Siegel (2017) and Cruz (2019) show that human capital is another important driver of structural transformation. Caselli and Coleman (2001) reveal how workers' skills differ across economic sectors. Skilled labor is increasing in all sectors across countries, affecting relative prices and investment in physical capital and making some economic sectors more productive than others. Therefore, skilled workers might drive structural change to different paths. In particular, there are two paths of structural transformation in which skilled workers can be placed. The first determines that the economy moves towards low TFP sectors and, then, skilled workers might go there. The second path is a skilled-biased structural change.

Beginning with the first path, Baumol (1967) claimed that if the proportion of output remains between a stagnant sector (with constant labor productivity) and a progressive sector (with increasing labor productivity), production costs and prices would tend to rise in the stagnant sector. Therefore, the labor force would move from high TFP growth to low TFP growth sectors. This has been theoretically explained from the supply side or the demand side. From the supply side, Ngai and Pissarides (2007) show that structural change depends on the differences in TFP growth rates across sectors and the elasticity of substitution between the goods produced in these sectors. In particular, when TFP growth rates differ among sectors and the elasticity of substitution among the final goods produced in each sector is lower than one - that is, they are complements-, then labor moves from high TFP growth to low TFP growth sectors. From the demand side, Kongsamut et al. (2001) propose a general balanced growth model that is consistent with the Kaldor facts and the massive reallocation of labor from one sector to the others. They use Stone-Geary preferences ${ }^{5}$ to explain that when the income of households increases, the proportion of income spent on agricultural goods drops and the proportion spent on the other goods increases — that is, the Engel's Law—. Under a knife-edge condition, the

\footnotetext{
${ }^{5}$ Stone-Geary preferences are often used to model problems involving subsistence levels of consumption. That is, a certain minimal level of some good has to be consumed regardless of its price and the consumer income before the individual decides to spend a positive amount on other goods.
} 
economy grows at a constant rate while there is this shift towards the services sector.

The second path is a skill-biased structural change. This has been theoretically explained from a supply side or a demand side. From the demand side, Buera and Kaboski (2009, 2012) and Buera et al. (2018) describe the skill-biased structural change experienced in advanced economies ${ }^{6}$ through a two-sector model - a high skilled labor sector (services) and a low skilled labor sector (goods) - that explains the rise of the skill premium caused by technical change. They assume non-homothetic preferences such that the expenditure share of services increases in income. They show that differences in relative wages are given by changes in the relative supply of high skilled labor, skill-biased technological change and other technological changes. They also suggest that industries could be organized by skill intensity. From the supply side, Rogerson (2008) finds that relative increases in taxes and technological catch-up can account for most of the differences between the European and American time allocations. In the services sector, he considers two types of production: home production - non-taxed substitutive services for those produced in the market - and taxed market production. Since skilled workers are mostly in market services and their productivity is higher than that of unskilled workers, market services productivity grows faster than home productivity. Therefore, with an increase in skilled labor, these workers are reallocated into the market services sector and home production falls. He finds that hours worked in Europe decline by almost $45 \%$ compared to the U.S. over the analyzed period (1956-2003), which was almost entirely accounted for by the fact that Europe develops a much smaller market services sector than the U.S. Moreover, the U.S. has experienced a shift from home to market production. In addition, Timmer and de Vries (2009) find that productivity improvement in market services is greater than productivity growth in manufacturing. Herrendorf et al. (2014) show that sectoral productivity growth differences are the main factor behind structural transformation among broad sectors in the U.S. In a multi-sector model in

\footnotetext{
${ }^{6}$ Australia, Austria, Denmark, France, Germany, Italy, Japan, Netherlands, South Korea, Spain, United Kingdom, and the United States.
} 
which sector differences depend on human capital intensity, Herrendorf and Schoellman (2018) show that average wages in agriculture are lower than those in the other sectors and, at the same time, this sector has less educated workers. Thus, skilled workers end up in high TFP sectors. According to the skill-biased structural change, it seems that if a country increases its human capital, then it will reach this skill-biased structural change.

Acemoglu $(1998,2002)$ argues that there has been a directed technical change, at least for the U.S. He shows that the increase in relative skilled labor supply has two effects: a price effect and a market size effect. The elasticity of substitution between factors determines which of these two effects dominates. In particular, when both factors are complements, the price effect dominates and when both factors are weak substitutes ${ }^{7}$, the market size effect dominates and, then, the relative skilled wage increases at the same time that there is a skill-biased technical change. Then, according to Acemoglu (1998, 2002), an increase in relative skilled workers will induce a skill-biased structural change in the presence of directed technical change.

The aforementioned literature does not address questions related to the final stage of structural transformation across high and low income countries. It suggests that all economies might follow the same path. This paper highlights the importance of directed technical change in the final stage that an economy can reach during structural transformation when there is an increasing skilled labor supply. The rise of skilled workers might induce directed technical change or not. If these two phenomena do co-exist during structural change, an economy will end up in high TFP sectors. Similar to Kuralbayeva and Stefanski (2013), we develop macrodata and microdata approaches to identify the existence of directed technical change. However, we consider more than just the traditional sectors - agriculture, industry and services - . Buera et al. (2018) and Duernecker et al. (2017) also suggest a wider division of sectors. We find that the existence of di-

\footnotetext{
${ }^{7}$ In particular, the elasticity of substitution has to be higher than 1 and lower than 2 . There is general consensus that this is the case between skilled and unskilled workers.
} 
rected technical change during structural transformation is needed for skilled workers to end up in high TFP sectors. Thus, not all the economies will necessarily follow the same pattern of structural change: some will end up in low TFP sectors - Low-Tech Industry and Unskilled Services - and some in high TFP sectors - High-Tech Industry and Skilled Market Services-. We show that directed technical change has occurred in high income countries such as the U.S., South Korea and France since the relative TFP of skilled sectors compared to unskilled ones has increased over time and relative wages are higher for tertiary educated workers who work in high TFP sectors. This finding can help us to understand why the gap in GDP per capita between South Korea and the U.S. is shrinking over time. Canada has not experienced a directed technical change and, then, its skilled workers have ended up in low TFP sectors during structural change. There is a lack of clear evidence of directed technical change for Italy and Spain.

\section{Macrodata Evidence}

It is important to analyze how structural transformation has taken place in several economies. The usual structural transformation has been characterized by shifting the value added (and the labor force) out of the agriculture sector and allocating it first to the industry sector and, after, to the services sector. We analyze this structural transformation by dividing the economy into six sectors: Agriculture, Low-Tech Industry, HighTech Industry, Unskilled Services, Skilled Market Services, and Skilled Non-Market Services. We follow Herrendorf and Schoellman (2018), who consider that skilled services are those that employ workers with at least thirteen years of education on average, and Dix-Carneiro (2014), who uses the OECD criterion that classifies industries according to their technology intensity in the report "Towards a Knowledge Based Economy" 8 . We

\footnotetext{
${ }^{8}$ In addition to Herrendorf and Schoellman (2018), we classify the skilled services sector into Skilled Market Services (finance and insurance activities, real state activities, professional, scientific, technical, administrative and support service activities, and utilities) and Skilled Non-Market Services (education, health and public administration, and defense). The Skilled Market Services sector is defined as the sector that uses high skilled labor at the same time that prices and wages are determined by the market. This latter assumption is important given that the income determined by these prices is expected to be higher than in other market sectors. We make the distinction between Market and Non-Market Skilled Services because it is the government that
} 
use EU KLEMS and WORLD KLEMS databases, which have sector information about value added, labor and capital for some countries. Figure 1 shows the share of value added of our six sectors for Canada, France, Italy, South Korea, Spain, and the U.S. ${ }^{9}$. We can see that the share of the value added of the Agriculture sector has decreased in all countries over time, as structural change theories predict. The Skilled Market Services sector, a high TFP sector, also shows an increasing behavior in all these countries. In the U.S., this sector produced $20.36 \%$ of the total value added in 1970 and rose to $31.69 \%$ in 2015. The Unskilled Services sector rose considerably in Spain only; it produced $21.64 \%$ of the total value added in 1970 and $31.43 \%$ in 2017 . Spain is the only country where this sector has the highest level of value added. South Korea is the only country that exhibits an increasing tendency in the High-Tech Industry sector (in addition to the Skilled Market Services sector, the other high TFP sector). This sector produced $5.71 \%$ of the total value added in 1970 , which rose to $21.76 \%$ in 2012 . France, Italy and the U.S. show similar patterns in production but have shifted from Unskilled Services to Skilled Market Services in different periods of time. Canada shows relatively constant behavior of its sectors over time. Figure 2 compares the shares of the value added produced by high TFP sectors relative to the U.S. The share of value added of the High-Tech Industry sector in South Korea is much higher than in the U.S. over time and shows a constant increase. The other analyzed countries show declining and lower shares of the value added of this sector compared to the U.S. Regarding the Skilled Market Services, South Korea shows a constant increase in the share of value added of this sector, but it is still lower than

decides the wages and, therefore, the value added in the Skilled Non-Market Services. In fact, and in general, these wages are the same for the same job in the geographical area they are provided. These skilled services have a greater resemblance to market services when they are provided at regional or municipal level. Then, wages do not necessarily capture the differences in productivity between skilled and unskilled workers. Furthermore, we also divide the industry sector into High-Tech and Low-Tech Industry, as in Dix-Carneiro (2014), classifying according to the technology intensity. High-Tech Industry includes alcohol production, nuclear fuels, oil refining, coke, chemical products, machinery and equipment, office, accounting and computing machinery, electrical machinery and apparatus, radio, television and communications equipment, medical, precision and optical instruments, motor vehicles, trailers and semi-trailers, and other transportation equipment. Low-Tech Industry includes food and beverage, tobacco products, textiles, apparel, leather products and footwear, wood products, paper, cellulose, paper products, editing and printing, rubber and plastic products, non-metallic mineral products, basic metals, fabricated metal products (except machinery and equipment), furniture, and recycling.

${ }^{9}$ Given that in Section 4 we make a complementary analysis with microdata information, we will refer only to those countries for which we have available data at both levels - micro and macro-. 
the U.S. The evolution of this sector in France is similar to the U.S. The other European countries - Spain and Italy - also show increasing shares of the value added of this sector compared to the U.S. but a slower rate than South Korea.

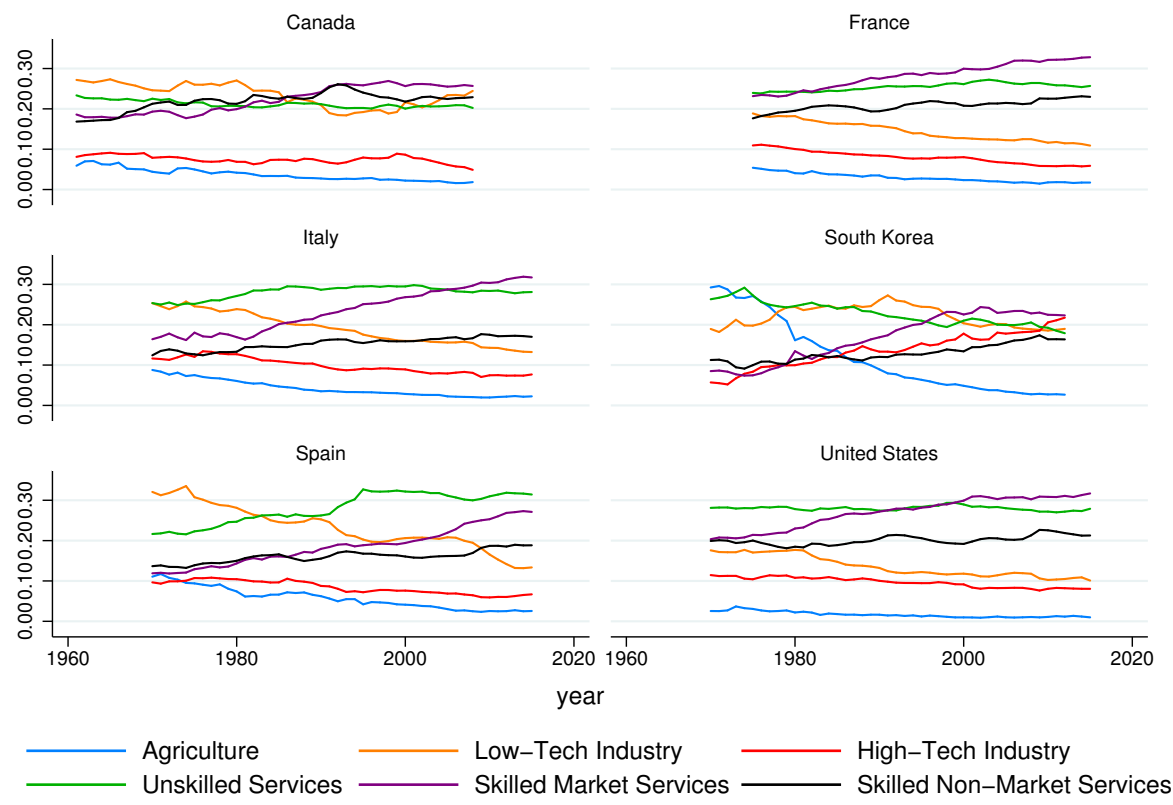

Fig. 1. Share of Value Added

Source: EU KLEMS and WORLD KLEMS Databases. 
High-Tech Industry

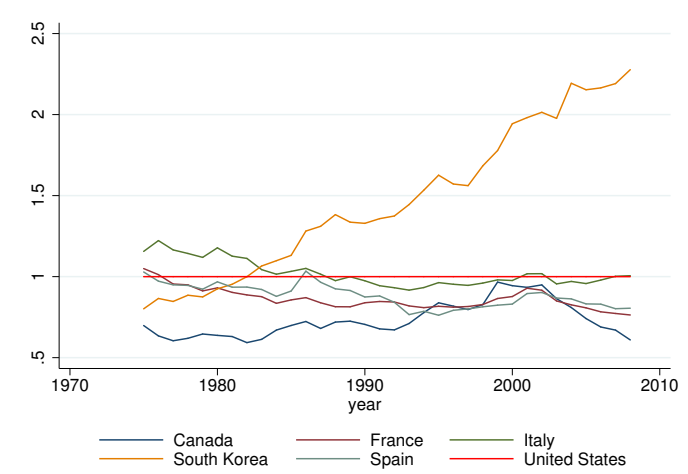

Skilled Market Services

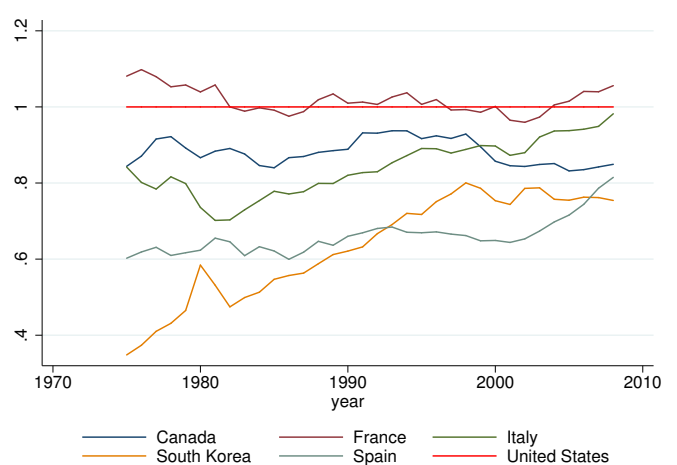

Fig. 2. Share of Value Added Compared to the U.S.

Source: EU KLEMS and WORLD KLEMS Databases.

Having described the value added evolution, we now look at the reallocation of the labor force. Figure 3 shows that the labor force has been allocated as structural change theories suggest — from agriculture to industry and, then, from industry to services - In Italy, South Korea and Spain the labor force has been allocated mostly in the Unskilled Services sector over time. Canada and France have allocated the labor force into the Unskilled Services and the Skilled Non-Market Services sectors. In the U.S., the labor force in the Skilled Market Services sector has increased over time and has extended to nearly the same level of labor force in the Unskilled Services and the Skilled Non-Market Services sectors. Figure 4 shows that the share of labor allocated into the High-Tech Industry in South Korea and Italy is higher than in the U.S. while the share of labor allocated into the Skilled Market Services sector in all of the analyzed countries is low 
compared to the U.S. ${ }^{10}$.

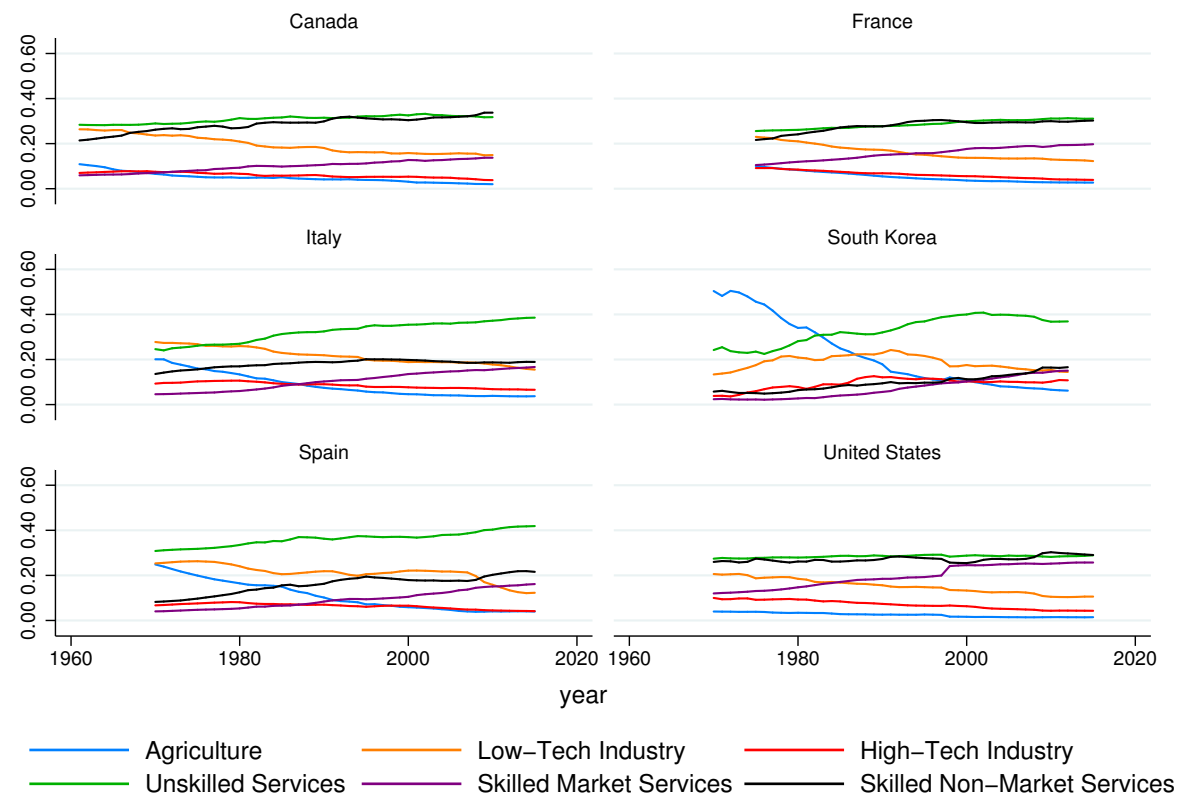

Fig. 3. Share of Labor

Source: EU KLEMS and WORLD KLEMS Databases.

$\overline{10}$ The shares of value added and labor compared to the U.S. for the other sectors are illustrated in the Appendix, as well as the shares of capital. 
High-Tech Industry

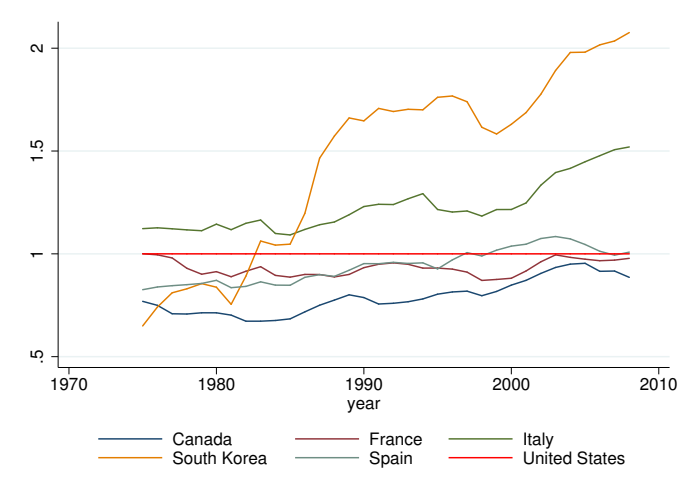

Skilled Market Services

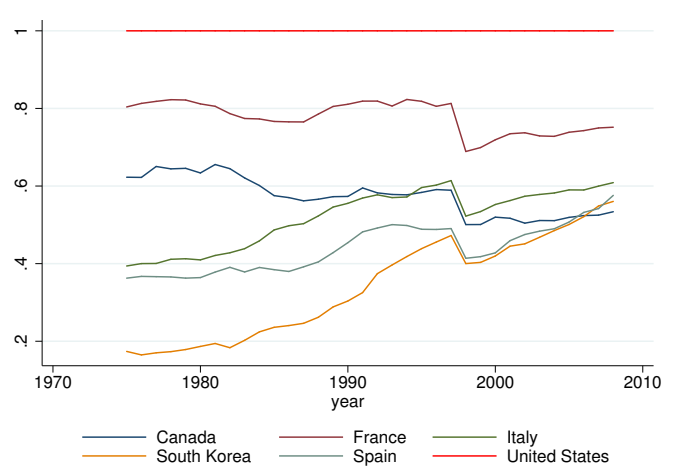

Fig. 4. Share of Labor of Compared to the U.S.

Source: EU KLEMS and WORLD KLEMS Databases.

Our objective is to determine whether an increase of skilled labor supply ${ }^{11}$ leads an economy towards high income levels. It is expected that if the increasing skilled labor supply is allocated in high TFP sectors, then the economy would end up in high income levels, since the value added produced by these sectors is always higher. Figure 5 shows that the value added of high TFP sectors indeed depends positively on the increase in the skilled labor force in the U.S., France, South Korea, Italy and Spain whereas it depends negatively on this increase in Canada ${ }^{12}$. This evidence shows that the increase of the skilled labor supply alone does not determine whether the economy will end up in high income levels. We argue that an economy ends up in high income levels if directed technical change exists at the same time that there is an increase in the skilled labor

\footnotetext{
$\overline{11}$ Figure 11 in the Appendix shows the increase in skilled labor supply across countries over time.

12 The results of the linear fit are given in Tables 9 and 10 in the Appendix.
} 
supply. As a result, if these two phenomena coexist, the gap in GDP per capita relative to the U.S. would shrink over time, as in South Korea ${ }^{13}$ (South Korean GDP per capita increased from 17.37\% of U.S. GDP in 1980 to $66.27 \%$ in 2017); see Figure 6.

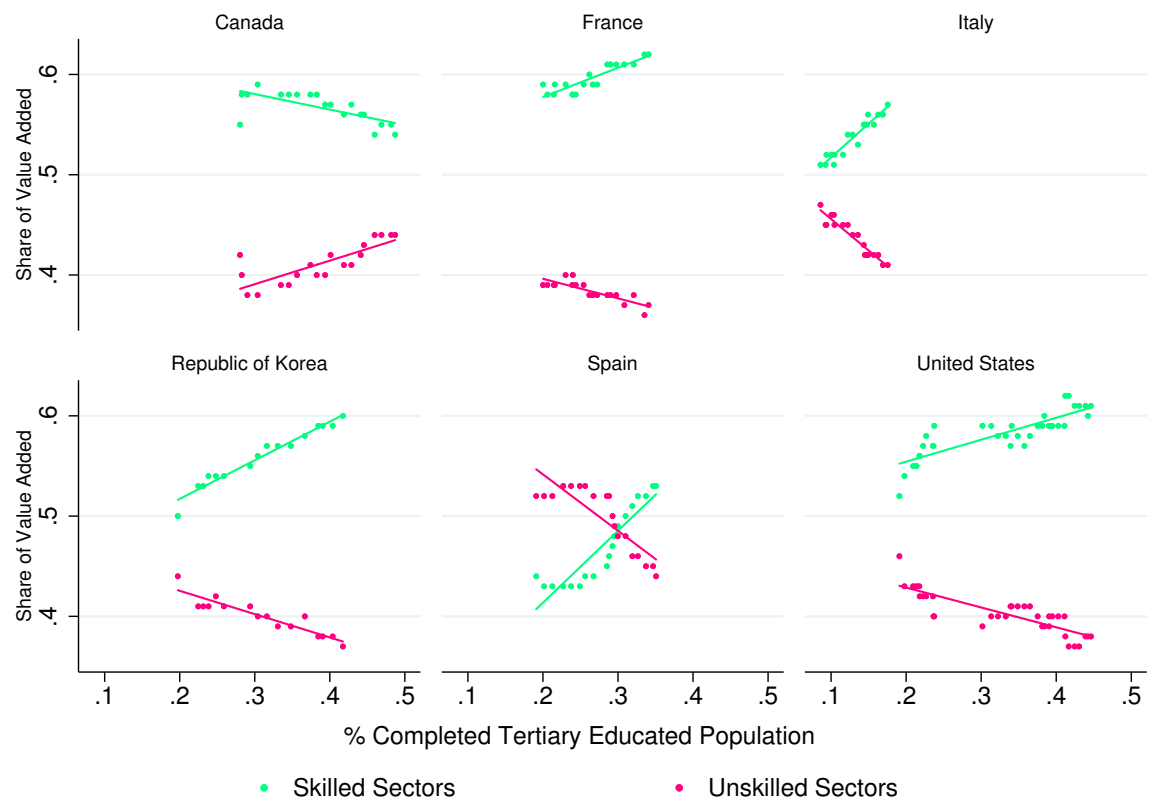

Fig. 5. Share of Value Added of the Skilled and Unskilled Sectors vs Completed Tertiary Educated Population. Source: World Economic Outlook and OECD.

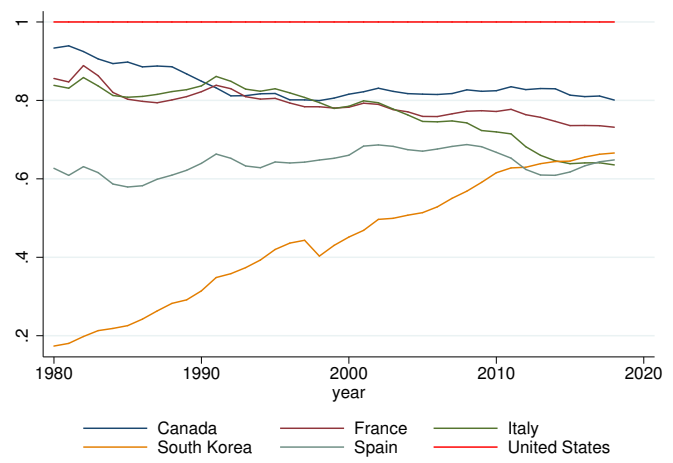

Fig. 6. GDP per Capita Relative to U.S. GDP per Capita.

Source: World Economic Outlook.

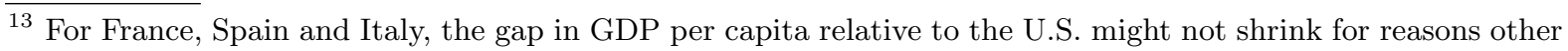
than the non-existence of directed technical change: a decline of the hours worked compared to the U.S., the high level of unemployment and the relatively small number of skilled workers; see Rogerson (2008). 
In light of this evidence, it seems that the two patterns of structural change discussed in Section 2 can emerge when different countries are analyzed. Some countries may allocate their skilled workers in high TFP sectors in the process of structural transformation and others may not. What is important to assess is whether the increase in skilled workers occurred with a directed technical change. If this is the case, an economy would end up at high income levels after structural transformation since skilled workers would be allocated to high TFP sectors. To identify whether directed technical change exists during the structural transformation, we first make a Solow residual decomposition for skilled sectors relative to unskilled ones. Through the analysis of relative TFP, we can determine whether directed technical change has existed at the same time as the increase in skilled labor supply. In Section 4, to corroborate the results of the Solow residual decomposition, we make a GLS estimation of wages as a function of usual variables such as the level of education and the economic sector.

\subsection{Solow Residual Decomposition}

Acemoglu (1998) considers a unique final good that is produced from two inputs: one using skilled labor and the other using unskilled labor. To have directed technical change, the elasticity of substitution between both inputs has to be between 1 and 2 . Instead we consider two different final goods in each sector: one produced using skilled labor and the other using unskilled labor, with elasticity of substitution between them in the utility function between 1 and 2. Thus, since the model is isomorphic to that of Acemoglu (1998), we would obtain the same conclusions. But now, we can do a Solow residual decomposition for each sector. This decomposition can be used to identify the relative supply of factors and, more importantly, the relative TFP. It is this relative TFP that will inform us whether directed technical change has existed.

Technology in each sector $i$ is

$$
Y_{i}=A_{i} K_{i}^{\alpha} L_{i}^{1-\alpha}
$$


where $Y_{i}$ is the production of sector $i, K_{i}$ is the amount of capital used in sector $i, L_{i}$ is the labor force allocated to sector $i$, and $A_{i}$ is the corresponding TFP for sector $i$. Taking logarithms on both sides of the equation and isolating the TFP term leads to

$$
\ln \left(A_{i}\right)=\ln \left(Y_{i}\right)-\alpha \ln \left(K_{i}\right)-(1-\alpha) \ln \left(L_{i}\right)
$$

Thus, the TFP for each sector can be identified. We assume the conventional value of $\alpha=1 / 3$ for the share of capital in income. Once the sector specific TFP has been found, we can compute the relative share of TFP between sector $i$ and $j$ as

$$
\ln \left(A_{i} / A_{j}\right)=\ln \left(Y_{i} / Y_{j}\right)-\alpha \ln \left(K_{i} / K_{j}\right)-(1-\alpha) \ln \left(L_{i} / L_{j}\right), i \neq j
$$

Given this equation, we can identify whether an increase in the relative skilled labor supply has indeed implied a directed technical change.

We calculate logarithms of the relative value added of the skilled sectors relative to the unskilled ones, the relative supply of labor, the relative accumulation of capital and the relative TFP. By analyzing the relative TFP we can conclude whether directed technical change has existed in the process of structural transformation and, then, whether the economy will end up in high income levels. If the relative TFP between skilled and unskilled sectors increases over time while there is also an increase in relative skilled labor, directed technical change has existed during structural transformation.

We use information provided in EU KLEMS and WORLD KLEMS databases. Basic and Capital Input Files are used to compute the shares of production — value added ${ }^{14}$ - labor and capital for the six sectors in the U.S., South Korea, Spain, Italy, France, and Canada. We use all the available information for each country ${ }^{15}$. We also use OECD

\footnotetext{
$\overline{14}$ See Buera et al. (2018).

${ }^{15}$ U.S. and Spain: from 1970 to 2015. South Korea: from 1970 to 2012 . Italy: from 1970 to 2015 for the value added and the share of labor and from 1995 to 2014 for the share of capital. France: from 1975 to 2015 for
} 
information about the tertiary educated population aged 25 and over.

Given that structural transformation moves towards the services sector, we first analyze the relative TFP of this sector. Figure 7 shows that in general the relative TFP of the Skilled (Skilled Market and Skilled Non-Market; solid line) and the Skilled Market (dashed line) Services relative to the Unskilled Services seems to increase over time for the analyzed countries (left axis) at the same time that the number of tertiary educated workers increased (right axis). Relative accumulation of capital has diminished and relative TFP has increased while the skilled labor supply has also increased for countries such as South Korea, France and the U.S. Spain's relative TFP seems to have increased only in the last five years and, therefore, the increase in relative value added might be explained only by the increase in the relative share of labor and not by the increase in relative TFP. Because of the few observations available for Italy and the behavior of the relative accumulation of capital for Canada that seems to be flat, we could have an ambiguous interpretation of the evolution of relative TFP for these countries ${ }^{16}$.

\footnotetext{
the value added and the share of labor and from 1978 to 2015 for the share of capital. Canada: from 1961 to 2010 for the shares of labor and capital and from 1961 to 2008 for the value added.

${ }^{16}$ If we analyze only the Skilled Market Services sector - dashed lines - we see that its relative TFP is above the relative TFP of the Skilled Services sector in all the countries. This fact indicates that the relative productivity of the Skilled Non-Market Services sector is lower than that of the Skilled Market Services sector. This means that the wages decided by the government are lower than those of the market.
} 

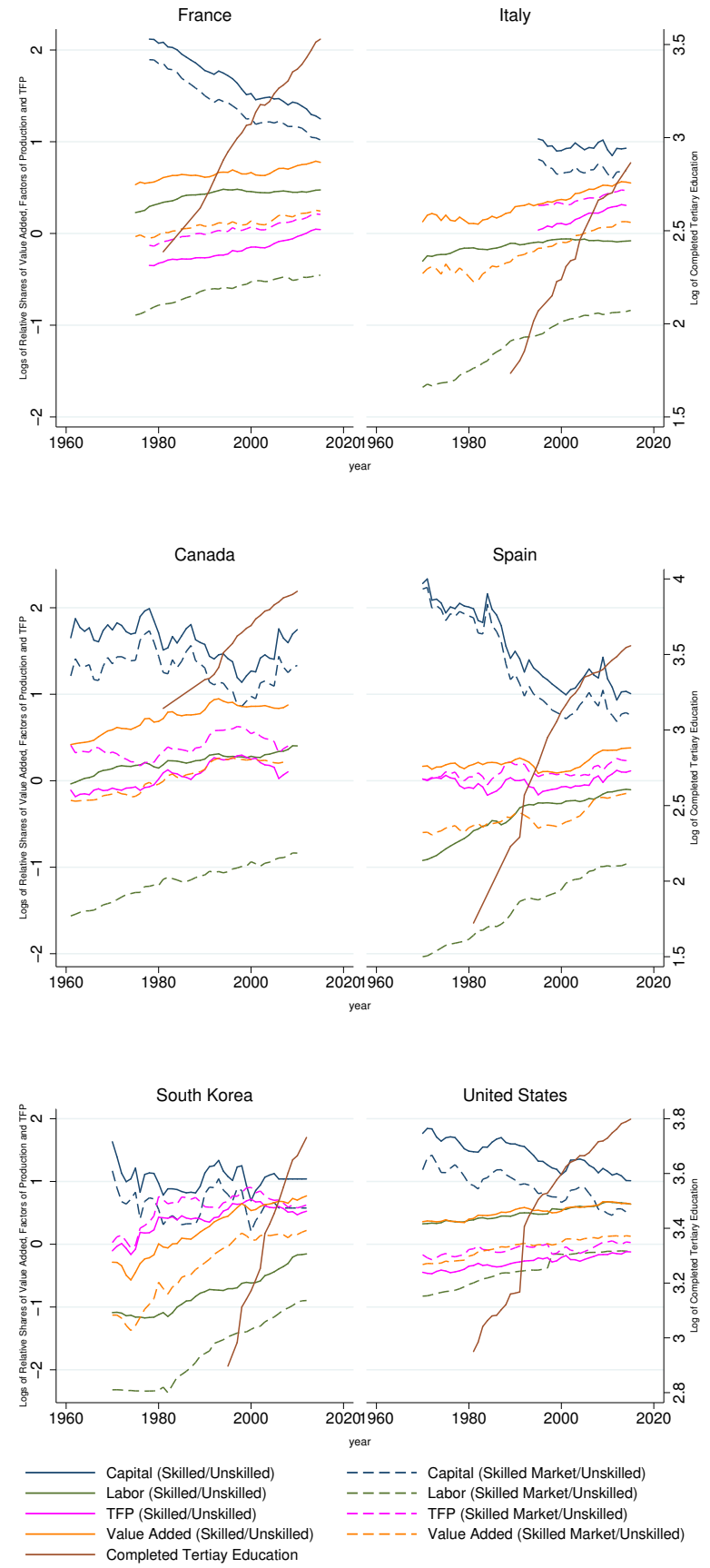

Fig. 7. Relative Value Added, Relative Supply of Labor, Relative Accumulation of Capital, Relative TFP of the Skilled (and Skilled Market) Services Sector vs the Unskilled Services Sector - Completed Tertiary Education. Source: EU KLEMS and WORLD KLEMS Databases.

Figure 8 shows the linear regression of the log of the relative TFP of the Skilled Services vs the Unskilled Services and the log of the share of completed tertiary educated population. The share of completed tertiary educated population has a positive impact 
on the relative TFP of the Skilled Services vs the Unskilled Services in France and the U.S. However, it shows a negative impact in South Korea. We believe that this unexpected finding for South Korea is due to the few observations we have on the share of completed tertiary educated population. For this variable we only have 17 out of the 43 observations that determine the evolution of relative TFP in South Korea. The share of completed tertiary educated population also has a negative impact on relative TFP in Canada, which suggests that directed technical change has not occurred. The share of completed tertiary educated population has a positive impact on relative TFP in Italy and Spain as well. However, previous findings in the behavior of the relative TFP prevent us from drawing relevant conclusions for these countries. Given the insights of Figures 7 and 8, we might conclude that a directed technical change has occurred in the Skilled Services and in the Skilled Market Services sectors for South Korea, France and the U.S. It seems that directed technical change in these sectors has not yet taken place in Canada, and for Spain and Italy we cannot draw convincing conclusions. 

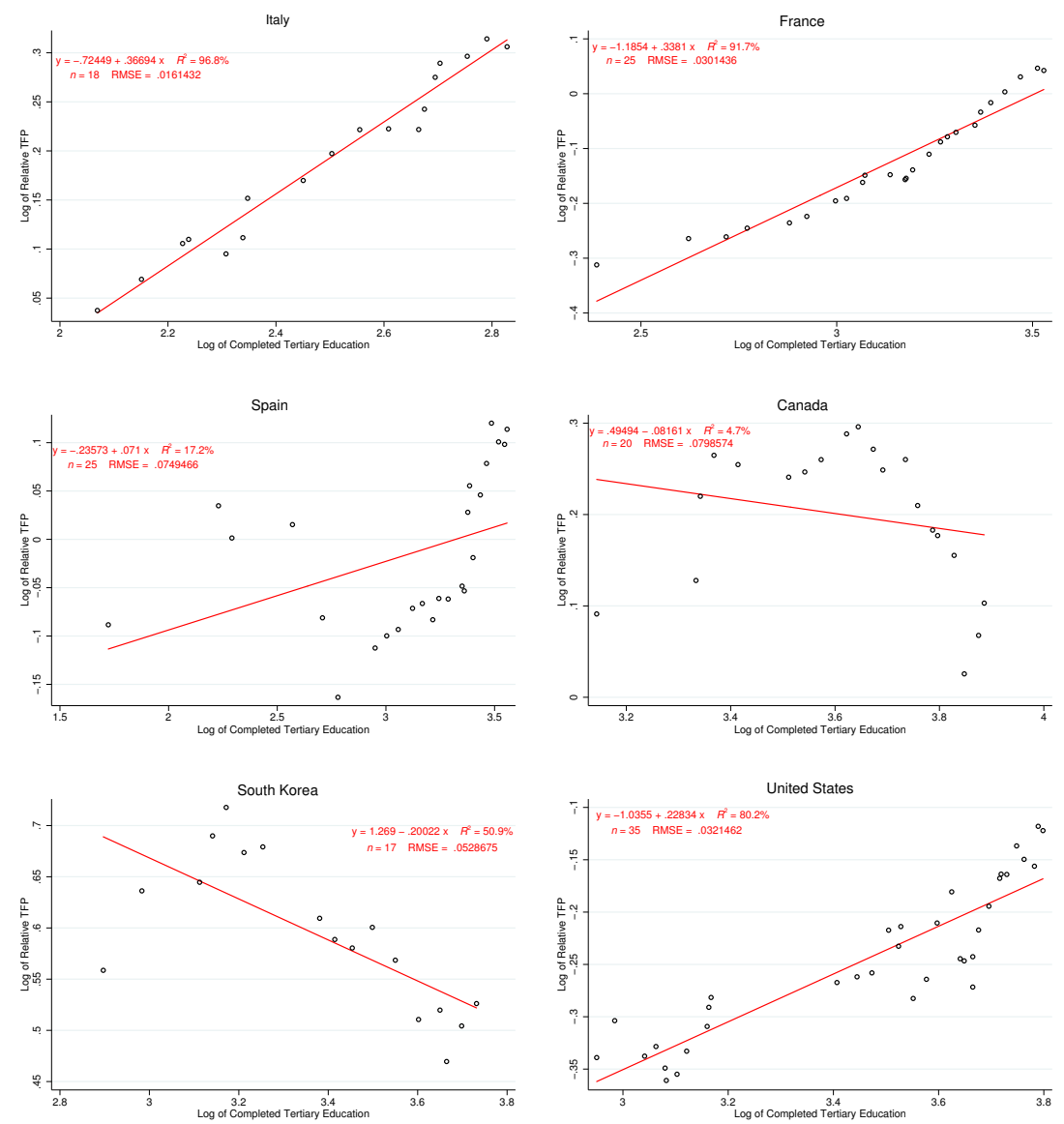

Fig. 8. Regression of the Log of the Relative TFP — Skilled Services vs Unskilled Services — and the Log of Completed Tertiary Education.

Source: EU KLEMS and WORLD KLEMS Databases.

We now group all the high TFP sectors (Skilled Services and High-Tech Industry) and repeat the same analysis. We see in Figure 9 that the relative TFP shows almost the same behavior as before for almost all the economies. Spain's relative TFP has a higher slope than before, which indicates that there may have been a directed technical change in the High-Tech Industry. In addition, the relative TFP of Canada shows a flatter path, which suggests that at least for Canada, a directed technical change in high TFP sectors has not yet occurred. For Italy, we cannot draw relevant conclusions due to the short period of time for the capital series, which prevents us from analyzing how that economy has evolved. 

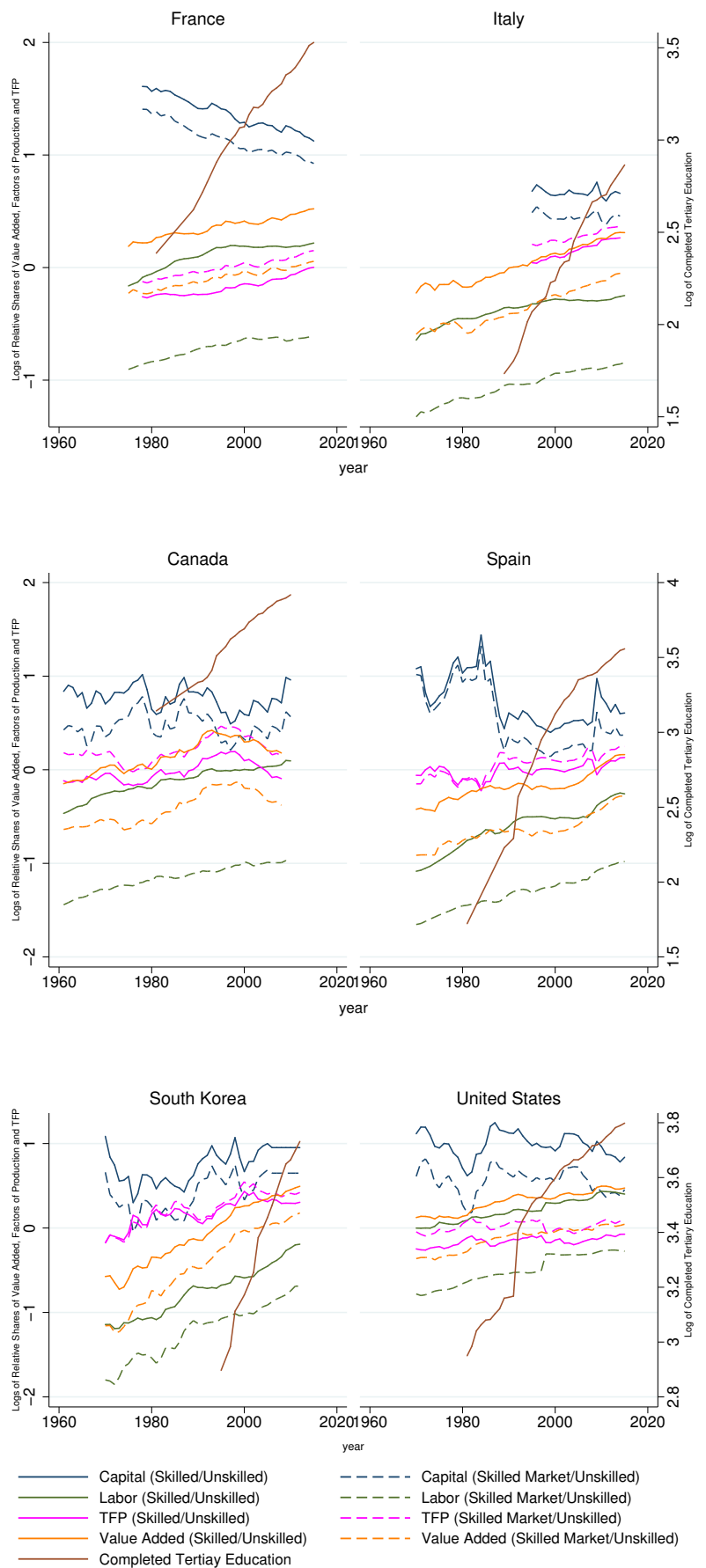

Fig. 9. Relative Value Added, Relative Supply of Labor, Relative Accumulation of Capital, Relative TFP of the Skilled (and Skilled Market) Sectors vs the Unskilled Sectors - Completed Tertiary Education.

Source: EU KLEMS and WORLD KLEMS Databases.

Figure 10 supports the insights from Figure 9. The share of completed tertiary educated population has a positive effect on the relative TFP of the Skilled Sectors vs the 
Unskilled Sectors in France and the U.S. South Korea again shows a negative slope. However, it is now flatter than that of Figure 8. As previously stated, we consider that this unexpected finding for South Korea is due to the few observations we have for the share of completed tertiary educated population. Furthermore, we see a more negative impact of the share of completed tertiary educated population on the relative TFP of these sectors in Canada, which is consistent with the insights described in previous paragraphs. Lastly, the share of completed tertiary educated population has a positive impact on the relative TFP in Italy and Spain, but we face the same restrictions as before for these countries.
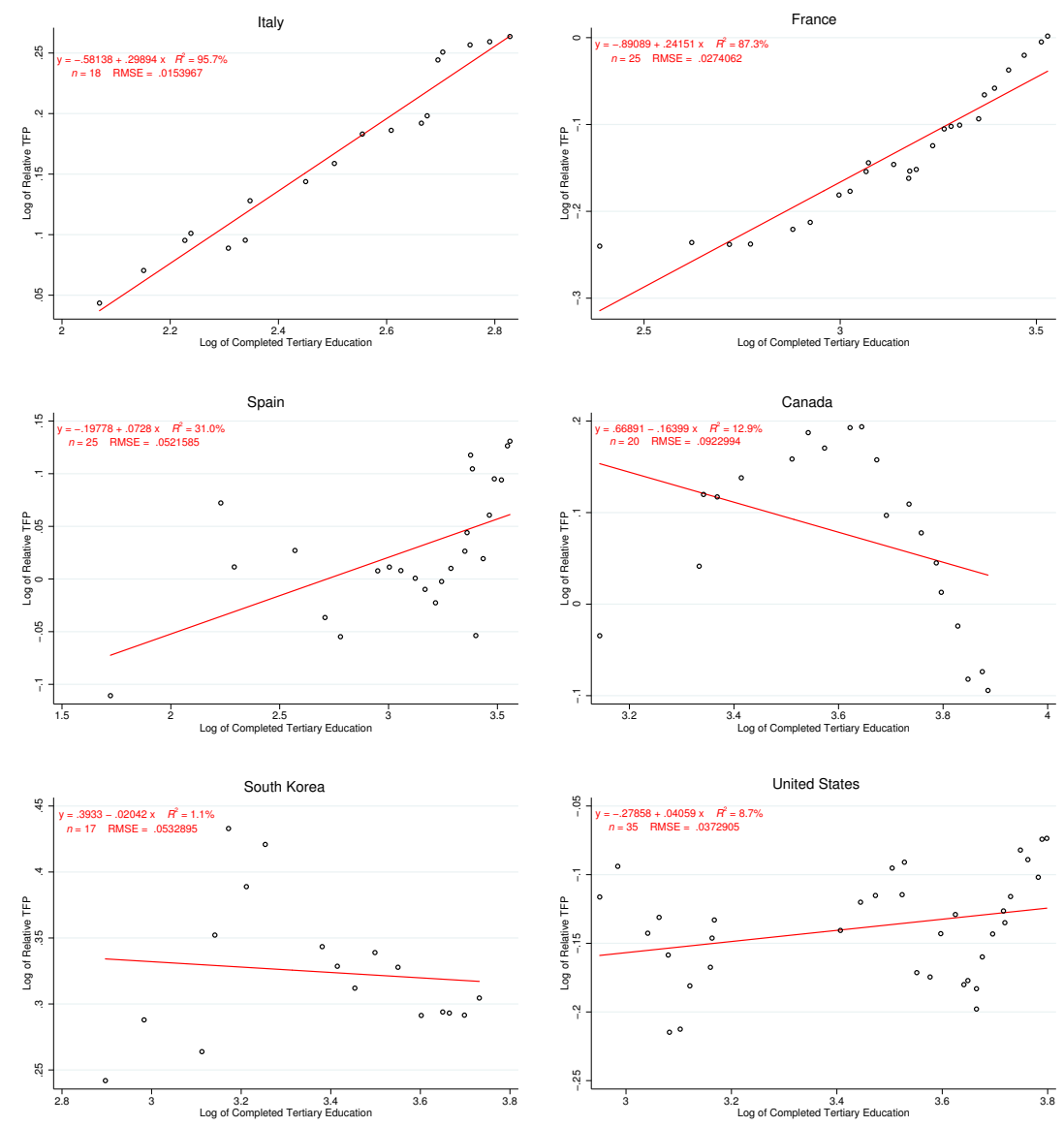

Fig. 10. Regression of the Log of the Relative TFP — Skilled Sectors vs Unskilled Sectors - and the Log of Completed Tertiary Education.

Source: EU KLEMS and WORLD KLEMS Databases.

From the analysis in this section, we conclude first that it is key to consider more economic subsectors than the usual three sectors, to gain a deeper understanding of how 
structural change has evolved across countries. Second, an increasingly skilled labor supply is only a necessary condition to shift structural transformation towards high income sectors, but directed technical change is also required as it leads to skilled workers ending up in high TFP sectors. Moreover, an economy will follow one of the two possible paths of structural transformation depending on the existence of directed technical change. If an economy experiences directed technical change during structural transformation, we would see that the relative TFP of the skilled sectors versus the unskilled sectors rises. We would also see a positive impact of the share of completed tertiary educated population on the relative TFP of sectors. This is the case of France, South Korea and the U.S. As Canada shows a flat relative TFP, and a negative impact of the share of completed tertiary educated population on the relative TFP of sectors, we argue that directed technical change has not yet occurred in this economy. In Spain, we argue that directed technical change might have existed in the High-Tech Industry as the relative TFP increases when we consider not only the services sector but the industry sector. We do not draw any certain conclusions about Italy since we have few observations on capital accumulation and, then, on the relative TFP. Finally, we argue that the existence of directed technical change might drive a reduction in the GDP per capita gap relative to the U.S., as in South Korea.

To confirm our findings in this section, we perform a GLS panel data estimation of wages as a function of education level and economic sectors. The results (in particular, the positive value and the significance of the coefficient of the interaction term between these variables) will inform us whether the increase in skilled labor supply has caused innovation by profit maximizing firms in the skilled sectors making the skill premium increase. This would lead to skilled workers ending up in high TFP sectors. 


\section{Microdata Evidence}

The existence of directed technical change implies that an increase in the supply of skilled labor relative to unskilled labor makes the profits of innovating skill-complementary technologies increase, which triggers an increase in skilled workers' wages. If we assume that labor supply is inelastic at a given period of time, each worker will choose the sector that provides the highest wage, since utility is increasing in the wage. Consequently, given that the production of each sector is an indirect function of wage, we make a panel data estimation $^{17}$ where the wage is the endogenous variable and specific characteristics of workers are used as exogenous variables. The model specification is

$$
\ln \left(w_{i j}\right)=\beta_{j} s_{j}+\beta_{x} X_{i j}+\beta_{E} E_{i j}+\beta_{I}\left(s_{j} E_{i j}\right)+\beta_{t} t+\epsilon_{i j}
$$

where $w_{i j}$ is the wage of worker $i$ in a company of sector $j, s_{j}$ is a sector dummy, $X_{i j}$ are controls for characteristics of the worker - age, age square, gender, and geographic area-, $E_{i j}$ is a dummy of the level of education of worker $i$ in sector $j, s_{j} E_{i j}$ is the interaction term between the level of education of worker $i$ and the economic sector $j$ of her company, $\beta_{t}$ is the time fixed effect, and $\epsilon_{i j}$ is an i.i.d. error with zero mean.

We expect that the Mincer returns for skilled workers - those with completed tertiary education - will be higher than those for unskilled workers - those with non-completed tertiary education - However, our emphasis is on the Mincer returns for skilled workers in high TFP sectors ${ }^{18}$. Therefore, we include the interaction term $s_{j} E_{i j}$. We expect the highest value and significance of the coefficient of the interaction term between skilled workers and high TFP sectors if directed technical change exists. Table 9 describes the sources used for our microdata analysis. As mentioned earlier, we only present results for countries that have information available at micro and macro levels and, then, compar-

\footnotetext{
$\overline{{ }^{17} \text { In the data }}$ sets used, we can identify an individual - or a household — in different periods of time. However, these data sets are unbalanced.

${ }^{18}$ We make the same classification for sectors as in Section 3; i.e., we create a variable with the classification of the main economic activity of the company into Agriculture, Low-Tech Industry, High-Tech Industry, Unskilled Services, Skilled Market Services, and Skilled Non-Market Services.
} 
isons can be done ${ }^{19}$.

Table 1. Sources of Information for the Panel Data Estimation.

\begin{tabular}{|c|c|}
\hline Country & Source \\
\hline U.S. & $\begin{array}{l}\text { IPUMS International: U.S. Labor Survey. } \\
\text { Yearly available data: 1960, 1970, 1980, 1990, 2000, 2005, } 2010 .\end{array}$ \\
\hline South Korea & $\begin{array}{l}\text { Korea Labor Institute: Korean Labor \& Income Panel Study } \\
\text { Yearly available data: from } 1998 \text { to } 2016 .\end{array}$ \\
\hline Canada & $\begin{array}{l}\text { Statistics Canada: Labor Force Survey. } \\
\text { Monthly available data: from } 1997 \text { to } 2015 .\end{array}$ \\
\hline France & $\begin{array}{l}\text { National Institute of Statistics and Economic Studies: } \\
\text { Labor Force Survey. } \\
\text { Quarterly available data: from } 2003 \text { to } 2012 .\end{array}$ \\
\hline Italy & $\begin{array}{l}\text { National Institute of Statistics: Labor Force Survey. } \\
\text { Quarterly available data: from } 2009 \text { to } 2018 .\end{array}$ \\
\hline Spain & $\begin{array}{l}\text { National Institute of Statistics: Wage Structure Survey. } \\
\text { Yearly available data: } 2010,2014 \text {. }\end{array}$ \\
\hline
\end{tabular}

In each data set, we drop those observations that did not have the required information to run the regression ${ }^{20}$. The main variables for the estimation such as wages, level of education and economic activity usually have some missing or unknown observations, so we drop these observations and perform the analysis with the remaining data set. We also use the CPI index (yearly, monthly or quarterly, depending on the frequency of the database) published by the OECD to calculate real wages and avoid ambiguous interpretations of salary increases owing to inflation. We use the Unskilled Services sector as the category of reference $^{21}$. Given that there are a varying number of geographic areas across countries, we group them into four groups based on the last available GDP for each area, since we believe that firms in major cities are more likely to pay higher salaries and, then, we must control for that. We use the $25 \%, 50 \%$, and $75 \%$ percentile of the GDP to create

19 IPUMS International has a wide data set at micro level for countries such as India, Indonesia, South Africa, Brazil, and others, which would have helped us to make a wider analysis. But the required information at macro level is not available for the value added, labor and accumulation of capital across sectors for these countries. Additionally, microdata information was requested for other countries for which we have information at macro level but, unfortunately, we could not access it.

${ }^{20}$ We do not use imputation techniques for individuals with missing or unknowns since these missing or unknowns are not only in the numerical variables but in the categorical variables. Moreover, the dropped observations had similar characteristics to observations that were kept for the estimation.

${ }^{21}$ We also use the Agriculture sector as the category of reference and we obtain the same conclusions for the existence of directed technical change; see Tables 11, 12, 13, 14, and 15 in the Appendix. 
these groups. The geographical areas included in the $25 \%$ percentile will be the reference category in our estimations. Tables 2 to 7 show the results of GLS panel data estimations for the six countries mentioned before. Model (1) does not include geographic controls nor time fixed effects. Model (2) includes geographic controls but no time fixed effects. Model (3) includes both. As this latter model gives the best estimates among the three models, we describe only its results below ${ }^{22}$.

Table 2 shows the results of the GLS estimation for the U.S. As expected, the coefficients of the interaction term between the level of education and the high TFP sectors (High-Tech Industry and Skilled Market Services) are the highest and significant. Wages increase more if a worker has tertiary education and works in the High-Tech Industry (12.7\% more) or in the Skilled Market Services (12.8\% more) rather than in the Unskilled Services. This means that a skilled worker employed at a company in one of these sectors has the highest wage and does not have any incentive to move towards another sector. Therefore, we can conclude that the increase in skilled labor supply has made profit maximizing firms invest in innovation in these high TFP sectors making productivity (and then wages) increase, implying at the same time an increase in the incentives for skilled workers to work in these sectors. As a result, we can confirm that a directed technical change has occurred in the U.S. in high TFP sectors. Thus, skilled workers have been allocated to these sectors during the structural transformation leading the economy towards high income levels.

In broader results, we see that Mincer returns for tertiary education are positively high. The wages of workers who have completed tertiary education are $54.2 \%$ on average higher than those of workers who have non-completed tertiary education. Wages in the High (and Low)-Tech Industry and the Skilled Market Services are higher than in the

\footnotetext{
${ }^{22}$ The Wage Structure Survey of Spain does not include any geographic area information. Therefore, Table 7 only shows model (1) — with no geographic controls and no time fixed effects - and model (2) — with no geographic controls but with time fixed effects-. The results of model (2) are described below.
} 
Unskilled Services: the High-Tech Industry pays wages that are $34.9 \%$ higher than the Unskilled Services, the Skilled Market Services 22.6\%, the Low-Tech Industry 18.1\%, and the Skilled Non-Market Services 14.0\%. Finally, firms in Regions 1 and 3 pay more than those in Region $4^{23}$.

Table 3 shows the results of the GLS estimation for South Korea. As expected, the coefficients of the interaction term between the level of education and the high TFP sectors are the highest and significant: the wage of a worker with tertiary education working in the High-Tech Industry is $53.7 \%$ higher than in the Unskilled Services, and $27.5 \%$ higher in the Skilled Market Services. This means that a skilled worker employed at a company in one of these sectors has the highest wage and does not have any incentive to move towards another sector. Similar to the U.S., we can say that the increase in skilled labor supply has made profit maximizing firms invest in innovation in these high TFP sectors, which makes productivity (and then wages) increase. At the same time, this implies an increase in incentives for skilled workers to move towards these sectors. Then, we can confirm that a directed technical change has occurred in South Korea as well. Thus, skilled workers have been allocated to high TFP sectors during structural transformation, which leads the economy towards high income levels and reduces the GDP per capita gap with the U.S.

More general results indicate that Mincer returns for tertiary education are positive. The wages of workers who have completed tertiary education are $12.9 \%$ on average higher than those of workers who have non-completed tertiary education. Wages are higher in the Skilled Non-Market Services, the Skilled Market Services, and the Low-Tech Industry relative to the Unskilled Services: the Skilled Non-Market Services pays wages $25.7 \%$ higher than the Unskilled Services, the Skilled Market Services 23.4\%, and the Low-Tech Industry $3.7 \%$, whereas the coefficient of the High-Tech Industry is not significant. Fi-

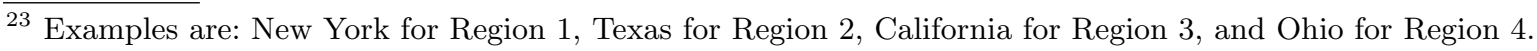


nally, firms located in areas producing more than $25 \%$ of total GDP pay more but their coefficients are not significant ${ }^{24}$.

Table 4 shows the results of the GLS estimation for France. As expected, the coefficients of the interaction term between the level of education and high TFP sectors are the highest and significant: the wage of a worker with tertiary education working in the High-Tech Industry is $16.2 \%$ higher than in the Unskilled Services and $8.3 \%$ higher if she works in the Skilled Market Services. This means that a skilled worker employed at a company in one of these sectors has the highest wage and does not have any incentive to move towards another sector. Similar to South Korea and the U.S., we can confirm that a directed technical change has existed for France in high TFP sectors. Thus, skilled workers have been allocated to these sectors during the structural transformation leading the economy towards high income levels.

In broader results, we see that Mincer returns are positive for tertiary educated workers. The wages of workers with tertiary education are $37.2 \%$ on average higher than those of workers who have non-completed tertiary education. As expected, wages are higher in all the sectors relative to the Unskilled Services: the Skilled Market Services and the Low-Tech Industry pay wages $7.2 \%$ higher than the Unskilled Services, the Skilled NonMarket Services 1.5\%, and the High-Tech Industry 0.3\%. Lastly, firms located in regions that produce more than $25 \%$ of the total GDP pay more ${ }^{25}$.

Table 5 shows the results of the GLS estimation for Canada. The information on age in this Labor Force Survey is a categorical variable and we group the data according to the OECD classification ${ }^{26}$. Mincer returns for tertiary education are positive. The wages of workers who have tertiary education are $27.1 \%$ on average higher than those workers who

\footnotetext{
${ }^{24}$ Examples are: Seoul for Region 1, Incheon for Region 2, Daegu for Region 3, and Gwangju for Region 4.

${ }^{25}$ Examples are: Paris for Region 1, Haute-Savoie for Region 2, Yvelines for Region 3, and Doubs for Region 4.

${ }^{26}$ See https://data.oecd.org/emp/employment-rate-by-age-group.htm.
} 
have non-completed tertiary education. The High-Tech Industry pays wages $46.4 \%$ higher than the Unskilled Services, the Low-Tech Industry 39.4\%, the Skilled Market Services $26.3 \%$, and the Skilled Non-Market Services 21.6\%. Workers with tertiary education earn $10.9 \%$ more if they work in the Skilled Non-Market Services rather than in the Unskilled Services and 3.7\% higher if they work in the Skilled Market Services. Therefore, workers have higher incentives to move towards the Skilled Non-Market Services. Firms located in regions that produce over $25 \%$ of total GDP pay more ${ }^{27}$. Considering these results and the insights for Canada in Section 3, we can conclude that a directed technical change has not taken place in this economy and, therefore, skilled workers will be allocated mainly to the Skilled Non-Market Services.

Table 6 shows the results of the GLS estimation for Italy. Mincer returns for tertiary education are positive. The wages of workers with tertiary education are $23.6 \%$ on average higher than those of workers with non-completed tertiary education. As expected, wages are higher in all sectors compared to the Unskilled Services: the Skilled Non-Market Services pay wages $20.5 \%$ higher than the Unskilled Services, the High-Tech Industry $18.2 \%$, the Low-Tech Industry 11.1\%, and the Skilled Market Services 8.1\%. Finally, firms located in Region 1 and 3 pay more ${ }^{28}$. Workers with tertiary education earn $11.1 \%$ more if they work in the Skilled Market Services rather than in the Unskilled Services and 8.1\% more if they work in the High-Tech Industry. Considering these results, at microdata level, we argue that directed technical change might have occurred in Italy. However, in Section 3 it was not possible to analyze how that economy has evolved at macro level. Then, we cannot draw any certain conclusions about the existence of directed technical change in Italy.

Table 7 shows the results of the GLS estimation for Spain. We only have two years of information (2010 and 2014) and therefore must be cautious about our conclusions.

\footnotetext{
${ }^{27}$ Examples are: Montreal for Region 1, Toronto for Region 2, Vancouver for Region 3, and Québec for Region 4.

${ }^{28}$ Examples are: Trentino alto Adige for Region 1, Toscana for Region 2, Lombardia for Region 3, and Abruzzo for Region 4.
} 
Mincer returns for tertiary education are also positive. Workers with tertiary education have wages $47 \%$ higher on average than those who have non-completed tertiary education. Wages are higher in the Industry sector (High-Tech and Low Tech) than in the Unskilled Services sector. The High-Tech Industry pays $34.3 \%$ more than the Unskilled Services while the Skilled Market Services pay less, although this coefficient is not significant. Workers with tertiary education earn $10.3 \%$ less if they work in the Low-Tech Industry rather than in the Unskilled Services, 9.0\% less if they work in the High-Tech Industry, $11.1 \%$ less if they work in the Skilled Non-Market Services, but $19.9 \%$ more if they work in the Skilled Market Services. Given these results, we argue that directed technical change might have occurred only in the Skilled Market Services in this country. However, in Section 3 we claimed that directed technical change might have existed in the High-Tech Industry but not in the Skilled Market Services. Therefore, the macrodata and microdata evidence are opposite and we cannot draw any certain conclusions about the existence of directed technical change in Spain.

Finally, Table 8 sums up the findings from macrodata and microdata evidence about the existence of directed technical change in the analyzed countries. 
Table 2. GLS Estimation of Wages of U.S.

\begin{tabular}{|c|c|c|c|}
\hline & $(1)$ & $(2)$ & (3) \\
\hline Age & $\begin{array}{c}0.141^{* * *} \\
(0.000)\end{array}$ & $\begin{array}{c}0.140^{* * * *} \\
(0.000)\end{array}$ & $\begin{array}{c}0.132^{* * * *} \\
(0.000)\end{array}$ \\
\hline $\mathrm{Age}^{2}$ & $\begin{array}{c}-0.001^{* * *} \\
(0.000)\end{array}$ & $\begin{array}{c}-0.001^{* * *} \\
(0.000)\end{array}$ & $\begin{array}{c}-0.001^{* * *} \\
(0.000)\end{array}$ \\
\hline Gender (Female) & $\begin{array}{c}-0.312^{* * *} \\
(0.001)\end{array}$ & $\begin{array}{c}-0.310^{* * *} \\
(0.001)\end{array}$ & $\begin{array}{c}-0.422^{* * *} \\
(0.000)\end{array}$ \\
\hline Education (Tertiary) & $\begin{array}{c}0.995^{* * * *} \\
(0.002)\end{array}$ & $\begin{array}{c}0.997^{* * *} \\
(0.002)\end{array}$ & $\begin{array}{c}0.542^{* * *} \\
(0.001)\end{array}$ \\
\hline Agriculture & $\begin{array}{c}-0.153^{* * *} \\
(0.003)\end{array}$ & $\begin{array}{c}-0.180^{* * *} \\
(0.003)\end{array}$ & $\begin{array}{c}-0.242^{* * *} \\
(0.001)\end{array}$ \\
\hline Low-Tech Industry & $\begin{array}{c}-0.177^{* * *} * \\
(0.001)\end{array}$ & $\begin{array}{c}-0.172^{* * *} * \\
(0.001)\end{array}$ & $\begin{array}{c}0.181^{* * *} * \\
(0.001)\end{array}$ \\
\hline High-Tech Industry & $\begin{array}{c}-0.211^{* * * *} \\
(0.002)\end{array}$ & $\begin{array}{c}-0.186^{* * * *} \\
(0.002)\end{array}$ & $\begin{array}{c}0.349 * * * \\
(0.001)\end{array}$ \\
\hline Skilled Market Services & $\begin{array}{c}0.308^{* * * *} \\
(0.001)\end{array}$ & $\begin{array}{c}0.310 * * * \\
(0.001)\end{array}$ & $\begin{array}{c}0.226^{* * *} \\
(0.001)\end{array}$ \\
\hline Skilled Non-Market Services & $\begin{array}{c}0.013^{* * *} * \\
(0.001)\end{array}$ & $\begin{array}{c}0.012^{* * *} \\
(0.001)\end{array}$ & $\begin{array}{c}0.140^{* * *} \\
(0.001)\end{array}$ \\
\hline Agriculture $*$ Education (Tertiary) & $\begin{array}{c}-0.053^{* * *} \\
(0.010)\end{array}$ & $\begin{array}{c}-0.043^{* * *} \\
(0.010)\end{array}$ & $\begin{array}{c}0.065^{* * *} * \\
(0.004)\end{array}$ \\
\hline Low-Tech Industry $*$ Education (Tertiary) & $\begin{array}{c}0.039^{* * *} \\
(0.004)\end{array}$ & $\begin{array}{c}0.039^{* * *} * \\
(0.004)\end{array}$ & $\begin{array}{c}0.039 * * * \\
(0.002)\end{array}$ \\
\hline High-Tech Industry $*$ Education (Tertiary) & $\begin{array}{c}0.377^{* * *} \\
(0.004)\end{array}$ & $\begin{array}{c}0.359 * * * \\
(0.004)\end{array}$ & $\begin{array}{c}0.127^{* * *} * \\
(0.002)\end{array}$ \\
\hline Skilled Market Services $*$ Education (Tertiary) & $\begin{array}{c}0.176^{* * *} \\
(0.003)\end{array}$ & $\begin{array}{c}0.177^{* * *} * \\
(0.003)\end{array}$ & $0.128^{* * *}$ \\
\hline Skilled Non-Market Services $*$ Education (Tertiary) & $\begin{array}{c}-0.122^{* * *} \\
(0.003)\end{array}$ & $\begin{array}{c}-0.120^{* * * *} \\
(0.003)\end{array}$ & $\begin{array}{c}-0.053^{* * *} * \\
(0.001)\end{array}$ \\
\hline Region 1 & - & $\begin{array}{l}-0.053^{* * *} \\
(0.001)\end{array}$ & $\begin{array}{c}0.056^{* * *} \\
(0.000)\end{array}$ \\
\hline Region 2 & - & $\begin{array}{c}0.152^{* * * *} \\
(0.001)\end{array}$ & $\begin{array}{l}-0.021^{* * *} * \\
(0.000)\end{array}$ \\
\hline Region 3 & - & $\begin{array}{c}0.214^{* * *} \\
(0.001)\end{array}$ & $\begin{array}{c}0.044^{* * *} \\
(0.000)\end{array}$ \\
\hline Constant & $\begin{array}{c}5.687^{* * *} \\
(0.003)\end{array}$ & $\begin{array}{c}5.606^{* * *} \\
(0.003)\end{array}$ & $\begin{array}{c}4.953^{* * *} \\
(0.002)\end{array}$ \\
\hline $\begin{array}{l}\text { Geographic Controls } \\
\text { Time Fixed Effects }\end{array}$ & $\begin{array}{l}\mathrm{NO} \\
\mathrm{NO}\end{array}$ & $\begin{array}{l}\text { YES } \\
\mathrm{NO}\end{array}$ & $\begin{array}{l}\text { YES } \\
\text { YES }\end{array}$ \\
\hline $\begin{array}{l}\text { Observations } \\
\text { R-squared } \\
\text { LR } \chi^{2} \\
\text { Prob }<\chi^{2}\end{array}$ & $\begin{array}{c}21,557,941 \\
0.133 \\
2.361 \mathrm{e}+05 \\
0.000\end{array}$ & $\begin{array}{c}21,557,941 \\
0.136 \\
1.989 \mathrm{e}+05 \\
0.000\end{array}$ & $\begin{array}{c}21,557,941 \\
0.853 \\
5.192 \mathrm{e}+06 \\
0.000\end{array}$ \\
\hline
\end{tabular}

Source: IPUMS International. 
Table 3. GLS Estimation of Wages of South Korea.

\begin{tabular}{|c|c|c|c|}
\hline & $(1)$ & $(2)$ & $(3)$ \\
\hline Age & $\begin{array}{c}0.071^{* * *} * \\
(0.003)\end{array}$ & $\begin{array}{c}0.072^{* * *} \\
(0.003)\end{array}$ & $\begin{array}{c}0.072^{* * *} \\
(0.003)\end{array}$ \\
\hline $\mathrm{Age}^{2}$ & $\begin{array}{c}-0.001^{* * *} \\
(0.000)\end{array}$ & $\begin{array}{c}-0.001^{* * *} * \\
(0.000)\end{array}$ & $\begin{array}{c}-0.001^{* * *} * \\
(0.000)\end{array}$ \\
\hline Gender (Female) & $\begin{array}{c}-0.465^{* * *} \\
(0.012)\end{array}$ & $\begin{array}{c}-0.465^{* * *} * \\
(0.012)\end{array}$ & $\begin{array}{c}-0.440 * * * \\
(0.011)\end{array}$ \\
\hline Education (Tertiary) & $\begin{array}{c}0.147^{* * *} \\
(0.022)\end{array}$ & $\begin{array}{c}0.147^{* * *} \\
(0.023)\end{array}$ & $\begin{array}{c}0.129^{* * *} \\
(0.022)\end{array}$ \\
\hline Agriculture & $\begin{array}{c}-0.164^{* * *} \\
(0.035)\end{array}$ & $\begin{array}{c}-0.165^{* * *} \\
(0.035)\end{array}$ & $\begin{array}{c}-0.128^{* * *} * \\
(0.034)\end{array}$ \\
\hline Low-Tech Industry & $\begin{array}{c}0.002 \\
(0.015)\end{array}$ & $\begin{array}{c}0.002 \\
(0.015)\end{array}$ & $\begin{array}{c}0.037^{* * *} * \\
(0.014)\end{array}$ \\
\hline High-Tech Industry & $\begin{array}{l}-0.001 \\
(0.028)\end{array}$ & $\begin{array}{l}0.001 \\
(0.028)\end{array}$ & $\begin{array}{l}-0.003 \\
(0.027)\end{array}$ \\
\hline Skilled Market Services & $\begin{array}{c}0.222^{* * *} \\
(0.020)\end{array}$ & $\begin{array}{c}0.222^{* * *} \\
(0.020)\end{array}$ & $\begin{array}{c}0.234^{* * *} * \\
(0.019)\end{array}$ \\
\hline Skilled Non-Market Services & $\begin{array}{c}0.279^{* * * *} \\
(0.027)\end{array}$ & $\begin{array}{c}0.278^{* * * *} \\
(0.027)\end{array}$ & $\begin{array}{c}0.257^{* * *} * \\
(0.026)\end{array}$ \\
\hline Agriculture $*$ Education (Tertiary) & $\begin{array}{c}0.357^{*} \\
(0.212)\end{array}$ & $\begin{array}{c}0.360^{*} \\
(0.212)\end{array}$ & $\begin{array}{c}0.284 \\
(0.204)\end{array}$ \\
\hline Low-Tech Industry $*$ Education (Tertiary) & $\begin{array}{c}0.123^{* * *} * \\
(0.036)\end{array}$ & $\begin{array}{c}0.121^{* * *} * \\
(0.036)\end{array}$ & $\begin{array}{c}0.080^{* *} \\
(0.035)\end{array}$ \\
\hline High-Tech Industry $*$ Education (Tertiary) & $\begin{array}{c}0.588^{* * *} \\
(0.057)\end{array}$ & $\begin{array}{c}0.589^{* * *} \\
(0.057)\end{array}$ & $\begin{array}{c}0.537^{* * *} * \\
(0.055)\end{array}$ \\
\hline Skilled Market Services $*$ Education (Tertiary) & $\begin{array}{c}0.307^{* * *} \\
(0.038)\end{array}$ & $\begin{array}{c}0.305^{* * *} * \\
(0.038)\end{array}$ & $\begin{array}{c}0.275^{* * *} * \\
(0.036)\end{array}$ \\
\hline Skilled Non-Market Services $*$ Education (Tertiary) & $\begin{array}{c}0.246^{* * *} \\
(0.040)\end{array}$ & $\begin{array}{c}0.246^{* * *} \\
(0.040)\end{array}$ & $\begin{array}{c}0.230^{* * *} \\
(0.039)\end{array}$ \\
\hline Region 1 & - & $\begin{array}{c}0.007 \\
(0.021)\end{array}$ & $\begin{array}{l}0.036^{*} \\
(0.020)\end{array}$ \\
\hline Region 2 & - & $\begin{array}{c}-0.050^{*} \\
(0.026)\end{array}$ & $\begin{array}{c}0.006 \\
(0.025)\end{array}$ \\
\hline Region 3 & - & $\begin{array}{l}-0.002 \\
(0.024)\end{array}$ & $\begin{array}{l}0.026 \\
(0.023)\end{array}$ \\
\hline Constant & $\begin{array}{c}-6.261^{* * *} \\
(0.058)\end{array}$ & $\begin{array}{c}-6.265^{* * * *} \\
(0.061)\end{array}$ & $\begin{array}{c}-6.581^{* * *} \\
(0.068)\end{array}$ \\
\hline $\begin{array}{l}\text { Geographic Controls } \\
\text { Time Fixed Effects }\end{array}$ & $\begin{array}{l}\mathrm{NO} \\
\mathrm{NO}\end{array}$ & $\begin{array}{l}\text { YES } \\
\text { NO }\end{array}$ & $\begin{array}{l}\text { YES } \\
\text { YES }\end{array}$ \\
\hline $\begin{array}{l}\text { Observations } \\
\text { R-squared } \\
\text { LR } \chi^{2} \\
\text { Prob }<\chi^{2}\end{array}$ & $\begin{array}{c}9,625 \\
0.308 \\
306 \\
0.000 \\
\end{array}$ & $\begin{array}{c}9,625 \\
0.309 \\
253 \\
0.000 \\
\end{array}$ & $\begin{array}{c}9,625 \\
0.365 \\
162 \\
0.000 \\
\end{array}$ \\
\hline
\end{tabular}

Source: Korea Labor Institute. 
Table 4. GLS Estimation of Wages of France.

\begin{tabular}{|c|c|c|c|}
\hline & $(1)$ & $(2)$ & $(3)$ \\
\hline Age & $\begin{array}{c}0.079 * * * \\
(0.001)\end{array}$ & $\begin{array}{c}0.079 * * * \\
(0.001)\end{array}$ & $\begin{array}{c}0.079 * * * \\
(0.001)\end{array}$ \\
\hline Age $^{2}$ & $\begin{array}{c}-0.001 * * * \\
(0.000)\end{array}$ & $\begin{array}{c}-0.001^{* * *} * \\
(0.000)\end{array}$ & $\begin{array}{c}-0.001^{* * *} \\
(0.000)\end{array}$ \\
\hline Gender (Female) & $\begin{array}{c}-0.326^{* * *} \\
(0.002)\end{array}$ & $\begin{array}{c}-0.318^{* * *} \\
(0.002)\end{array}$ & $\begin{array}{c}-0.318^{* * *} \\
(0.002)\end{array}$ \\
\hline Education (Tertiary) & $\begin{array}{c}0.392^{* * *} \\
(0.004)\end{array}$ & $\begin{array}{c}0.374^{* * *} \\
(0.004)\end{array}$ & $\begin{array}{c}0.372^{* * *} \\
(0.004)\end{array}$ \\
\hline Agriculture & $\begin{array}{c}-0.147^{* * * *} \\
(0.009)\end{array}$ & $\begin{array}{c}-0.137^{* * * *} \\
(0.009)\end{array}$ & $\begin{array}{c}-0.134^{* * *} \\
(0.009)\end{array}$ \\
\hline Low-Tech Industry & $\begin{array}{c}0.059^{* * *} \\
(0.003)\end{array}$ & $\begin{array}{c}0.070^{* * *} \\
(0.003)\end{array}$ & $\begin{array}{c}0.072^{* * *} \\
(0.003)\end{array}$ \\
\hline High-Tech Industry & $\begin{array}{c}-0.030 * * * \\
(0.003)\end{array}$ & $\begin{array}{l}-0.002 \\
(0.004)\end{array}$ & $\begin{array}{c}0.003^{* * *} * \\
(0.004)\end{array}$ \\
\hline Skilled Market Services & $\begin{array}{c}0.080 * * * \\
(0.003)\end{array}$ & $\begin{array}{c}0.067^{* * *} * \\
(0.003)\end{array}$ & $\begin{array}{c}0.072^{* * *} \\
(0.003)\end{array}$ \\
\hline Skilled Non-Market Services & $\begin{array}{c}0.013^{* * *} \\
(0.003)\end{array}$ & $\begin{array}{c}0.015^{* * *} \\
(0.003)\end{array}$ & $\begin{array}{c}0.015^{* * *} \\
(0.003)\end{array}$ \\
\hline Agriculture $*$ Education (Tertiary) & $\begin{array}{c}-0.053 * * \\
(0.024)\end{array}$ & $\begin{array}{c}-0.048^{* *} \\
(0.024)\end{array}$ & $\begin{array}{c}-0.048^{* *} \\
(0.024)\end{array}$ \\
\hline Low-Tech Industry $*$ Education (Tertiary) & $\begin{array}{c}0.020^{* * *} \\
(0.007)\end{array}$ & $\begin{array}{c}0.025^{* * *} \\
(0.007)\end{array}$ & $\begin{array}{c}0.026^{* * *} \\
(0.007)\end{array}$ \\
\hline High-Tech Industry $*$ Education (Tertiary) & $\begin{array}{c}0.180^{* * *} \\
(0.007)\end{array}$ & $\begin{array}{c}0.163^{* * *} \\
(0.007)\end{array}$ & $\begin{array}{c}0.162^{* * *} \\
(0.007)\end{array}$ \\
\hline Skilled Market Services $*$ Education (Tertiary) & $\begin{array}{c}0.079^{* * *} \\
(0.006)\end{array}$ & $\begin{array}{c}0.084^{* * *} * \\
(0.006)\end{array}$ & $\begin{array}{c}0.083^{* * *} \\
(0.006)\end{array}$ \\
\hline Skilled Non-Market Services $*$ Education (Tertiary) & $\begin{array}{c}0.030^{* * *} * \\
(0.005)\end{array}$ & $\begin{array}{c}0.037^{* * *} \\
(0.005)\end{array}$ & $\begin{array}{c}0.038^{* * *} \\
(0.005)\end{array}$ \\
\hline Region 1 & - & $\begin{array}{c}0.178 * * * \\
(0.002)\end{array}$ & $\begin{array}{c}0.178 * * * \\
(0.002)\end{array}$ \\
\hline Region 2 & - & & $\begin{array}{c}0.086^{* * *} \\
(0.003)\end{array}$ \\
\hline Region 3 & - & $\begin{array}{c}0.129^{* * *} \\
(0.002)\end{array}$ & $\begin{array}{c}0.129 * * * \\
(0.002)\end{array}$ \\
\hline Constant & $0.990 * * *$ & $\begin{array}{c}0.879 * * * \\
(0.011)\end{array}$ & $\begin{array}{c}0.852^{* * *} \\
(0.012) \\
\end{array}$ \\
\hline $\begin{array}{l}\text { Geographic Controls } \\
\text { Time Fixed Effects }\end{array}$ & $\begin{array}{l}\mathrm{NO} \\
\mathrm{NO}\end{array}$ & $\begin{array}{l}\text { YES } \\
\text { NO }\end{array}$ & $\begin{array}{l}\text { YES } \\
\text { YES }\end{array}$ \\
\hline Observations & 416,896 & 416,896 & 416,896 \\
\hline $\mathrm{R}$-squared & 0.230 & 0.241 & 0.241 \\
\hline $\begin{array}{l}\operatorname{LR} \chi^{2} \\
\operatorname{Prob}<\chi^{2}\end{array}$ & 8892 & 7775 & 2369 \\
\hline$\underline{\operatorname{Prob}}<\chi^{2}$ & 0.000 & 0.000 & 0.000 \\
\hline
\end{tabular}

Source: National Institute of Statistics and Economic Studies. 
Table 5. GLS Estimation of Wages of Canada.

\begin{tabular}{|c|c|c|c|}
\hline & $(1)$ & $(2)$ & $(3)$ \\
\hline Age $(25-54$ years old $)$ & $\begin{array}{c}0.794^{* * * *} \\
(0.001)\end{array}$ & $\begin{array}{l}0.792^{* * *} \\
(0.001)\end{array}$ & $\begin{array}{l}0.796^{* * *} \\
(0.001)\end{array}$ \\
\hline Age (55-64 years old) & $\begin{array}{c}0.713^{* * *} * \\
(0.001)\end{array}$ & $\begin{array}{c}0.711^{* * *} * \\
(0.001)\end{array}$ & $\begin{array}{c}0.704^{* * *} * \\
(0.001)\end{array}$ \\
\hline Gender (Female) & $\begin{array}{c}-0.349^{* * *} \\
(0.000)\end{array}$ & $\begin{array}{c}-0.350^{* * *} \\
(0.000)\end{array}$ & $\begin{array}{c}-0.350^{* * *} \\
(0.000)\end{array}$ \\
\hline Education (Tertiary) & $\begin{array}{c}0.277^{* * *} \\
(0.001)\end{array}$ & $\begin{array}{c}0.276^{* * *} \\
(0.001)\end{array}$ & $\begin{array}{c}0.271^{* * *} \\
(0.001)\end{array}$ \\
\hline Agriculture & $\begin{array}{c}0.130^{* * *} \\
(0.002)\end{array}$ & $\begin{array}{c}0.134^{* * *} \\
(0.002)\end{array}$ & $\begin{array}{c}0.136^{* * *} \\
(0.002)\end{array}$ \\
\hline Low-Tech Industry & $\begin{array}{c}0.392^{* * * *} \\
(0.001)\end{array}$ & $\begin{array}{c}0.393^{* * *} * \\
(0.001)\end{array}$ & $\begin{array}{l}0.394^{* * *} * \\
(0.001)\end{array}$ \\
\hline High-Tech Industry & $\begin{array}{c}0.457^{* * *} * \\
(0.001)\end{array}$ & $\begin{array}{c}0.457^{* * * *} \\
(0.001)\end{array}$ & $\begin{array}{c}0.464^{* * *} \\
(0.001)\end{array}$ \\
\hline Skilled Market Services & $0.264^{* * * *}$ & $0.261^{* * *} *$ & $0.263^{* * *}$ \\
\hline Skilled Non-Market Services & $\begin{array}{c}0.211^{* * *} * \\
(0.001)\end{array}$ & $\begin{array}{c}0.213^{* * *} \\
(0.001)\end{array}$ & $\begin{array}{c}0.216^{* * *} \\
(0.001)\end{array}$ \\
\hline Agriculture $*$ Education (Tertiary) & $\begin{array}{c}-0.080 * * * \\
(0.003)\end{array}$ & $\begin{array}{c}-0.079 * * * \\
(0.003)\end{array}$ & $\begin{array}{c}-0.078 * * * \\
(0.003)\end{array}$ \\
\hline Low-Tech Industry $*$ Education (Tertiary) & $\begin{array}{c}-0.110^{* * *} * \\
(0.001)\end{array}$ & $-0.109 * * *$ & $-0.110^{* * *}$ \\
\hline High-Tech Industry $*$ Education (Tertiary) & $\begin{array}{c}-0.096^{* * * *} \\
(0.002)\end{array}$ & $\begin{array}{c}-0.095^{* * *} * \\
(0.002)\end{array}$ & $\begin{array}{c}-0.096^{* * * *} \\
(0.002)\end{array}$ \\
\hline Skilled Market Services $*$ Education (Tertiary) & $\begin{array}{l}0.040 * * * \\
(0.001)\end{array}$ & $\begin{array}{c}0.039 * * * \\
(0.001)\end{array}$ & $\begin{array}{c}0.037 * * * \\
(0.001)\end{array}$ \\
\hline Skilled Non-Market Services $*$ Education (Tertiary) & $\begin{array}{c}0.111^{* * * *} \\
(0.001)\end{array}$ & $\begin{array}{c}0.111^{* * * *} \\
(0.001)\end{array}$ & $\begin{array}{c}0.109^{* * *} \\
(0.001)\end{array}$ \\
\hline Region 1 & - & $\begin{array}{c}0.091 * * * \\
(0.001)\end{array}$ & $\begin{array}{c}0.091 * * * \\
(0.001)\end{array}$ \\
\hline Region 2 & - & $\begin{array}{c}0.095^{* * *} \\
(0.001)\end{array}$ & $\begin{array}{c}0.095^{* * *} \\
(0.001)\end{array}$ \\
\hline Region 3 & - & $\begin{array}{c}0.042^{* * *} \\
(0.001)\end{array}$ & $\begin{array}{c}0.041^{* * *} \\
(0.001)\end{array}$ \\
\hline Constant & $\begin{array}{c}7.166^{* * *} \\
(0.001)\end{array}$ & $\begin{array}{c}7.118^{* * * *} \\
(0.001)\end{array}$ & $\begin{array}{c}7.044^{* * *} \\
(0.003)\end{array}$ \\
\hline $\begin{array}{l}\text { Geographic Controls } \\
\text { Time Fixed Effects }\end{array}$ & $\begin{array}{l}\mathrm{NO} \\
\mathrm{NO}\end{array}$ & $\begin{array}{l}\text { YES } \\
\text { NO }\end{array}$ & $\begin{array}{l}\text { YES } \\
\text { YES }\end{array}$ \\
\hline $\begin{array}{l}\text { Observations } \\
\text { R-squared } \\
\text { LR } \chi^{2} \\
\text { Prob }<\chi^{2} \\
\end{array}$ & $\begin{array}{c}11,728,036 \\
0.364 \\
478356 \\
0.000\end{array}$ & $\begin{array}{c}11,728,036 \\
0.365 \\
396184 \\
0.000 \\
\end{array}$ & $\begin{array}{c}11,728,036 \\
0.368 \\
27932 \\
0.000 \\
\end{array}$ \\
\hline
\end{tabular}

Standard errors in parentheses

*** $\mathrm{p}<0.01,{ }^{* *} \mathrm{p}<0.05,{ }^{*} \mathrm{p}<0.1$

Source: Statistics Canada. 
Table 6. GLS Estimation of Wages of Italy.

\begin{tabular}{|c|c|c|c|}
\hline & $(1)$ & $(2)$ & $(3)$ \\
\hline Age & $\begin{array}{c}0.039 * * * \\
(0.000)\end{array}$ & $\begin{array}{c}0.038 * * * \\
(0.000)\end{array}$ & $\begin{array}{c}0.038 * * * \\
(0.000)\end{array}$ \\
\hline $\mathrm{Age}^{2}$ & $\begin{array}{c}-0.000^{* * *} * \\
(0.000)\end{array}$ & $\begin{array}{c}-0.000^{* * *} \\
(0.000)\end{array}$ & $-0.000^{* * *}$ \\
\hline Gender (Female) & $\begin{array}{c}-0.283^{* * *} \\
(0.001)\end{array}$ & $\begin{array}{c}-0.290^{* * *} \\
(0.001)\end{array}$ & $\begin{array}{c}-0.290^{* * *} \\
(0.001)\end{array}$ \\
\hline Education (Tertiary) & $\begin{array}{c}0.240^{* * *} \\
(0.002)\end{array}$ & $\begin{array}{c}0.234^{* * *} \\
(0.002)\end{array}$ & $\begin{array}{c}0.236^{* * *} \\
(0.002)\end{array}$ \\
\hline Agriculture & $\begin{array}{l}-0.227^{* * * *} \\
(0.002)\end{array}$ & $\begin{array}{c}-0.202^{* * *} \\
(0.002)\end{array}$ & $\begin{array}{c}-0.203^{* * *} \\
(0.002)\end{array}$ \\
\hline Low-Tech Industry & $\begin{array}{c}0.115^{* * *} \\
(0.001)\end{array}$ & $\begin{array}{c}0.112^{* * * *} \\
(0.001)\end{array}$ & $\begin{array}{c}0.111^{* * *} * \\
(0.001)\end{array}$ \\
\hline High-Tech Industry & $\begin{array}{c}0.199^{* * *} * \\
(0.001)\end{array}$ & $\begin{array}{c}0.183^{* * *} \\
(0.001)\end{array}$ & $\begin{array}{c}0.182^{* * *} \\
(0.001)\end{array}$ \\
\hline Skilled Market Services & $\begin{array}{c}0.084^{* * *} \\
(0.001)\end{array}$ & $\begin{array}{c}0.082^{* * *} \\
(0.001)\end{array}$ & $\begin{array}{c}0.081^{* * *} * \\
(0.001)\end{array}$ \\
\hline Skilled Non-Market Services & $\begin{array}{c}0.199^{* * *} * \\
(0.001)\end{array}$ & $\begin{array}{c}0.207^{* * *} * \\
(0.001)\end{array}$ & $\begin{array}{c}0.205^{* * * *} \\
(0.001)\end{array}$ \\
\hline Agriculture $*$ Education (Tertiary) & $\begin{array}{c}0.115^{* * *} \\
(0.012)\end{array}$ & $\begin{array}{c}0.104^{* * *} \\
(0.012)\end{array}$ & $\begin{array}{c}0.102^{* * *} \\
(0.012)\end{array}$ \\
\hline Low-Tech Industry $*$ Education (Tertiary) & $\begin{array}{c}0.068^{* * *} \\
(0.004)\end{array}$ & $\begin{array}{c}0.065^{* * *} * \\
(0.004)\end{array}$ & $\begin{array}{c}0.067^{* * *} * \\
(0.004)\end{array}$ \\
\hline High-Tech Industry $*$ Education (Tertiary) & $\begin{array}{c}0.073^{* * *} \\
(0.003)\end{array}$ & $\begin{array}{c}0.082^{* * *} \\
(0.003)\end{array}$ & $\begin{array}{c}0.081^{* * *} * \\
(0.003)\end{array}$ \\
\hline Skilled Market Services $*$ Education (Tertiary) & $0.111^{* * *}$ & $\begin{array}{c}0.112^{* * *} \\
(0.003)\end{array}$ & $\begin{array}{c}0.111^{* * *} * \\
(0.003)\end{array}$ \\
\hline Skilled Non-Market Services $*$ Education (Tertiary) & $\begin{array}{c}0.006^{* * *} \\
(0.002)\end{array}$ & $\begin{array}{c}0.011^{* * *} * \\
(0.002)\end{array}$ & $\begin{array}{c}0.011^{* * *} \\
(0.002)\end{array}$ \\
\hline Region 1 & - & $\begin{array}{c}0.008 * * * \\
(0.002)\end{array}$ & $\begin{array}{c}0.008 * * * \\
(0.002)\end{array}$ \\
\hline Region 2 & - & & $\begin{array}{c}-0.020^{* * * *} \\
(0.002)\end{array}$ \\
\hline Region 3 & - & $\begin{array}{c}0.078^{* * * *} \\
(0.001)\end{array}$ & $\begin{array}{c}0.078^{* * *} \\
(0.001)\end{array}$ \\
\hline Constant & $\begin{array}{c}6.111^{* * *} \\
(0.004)\end{array}$ & $\begin{array}{c}6.095^{* * *} \\
(0.004) \\
\end{array}$ & $\begin{array}{c}6.130 * * * \\
(0.005) \\
\end{array}$ \\
\hline $\begin{array}{l}\text { Geographic Controls } \\
\text { Time Fixed Effects }\end{array}$ & $\begin{array}{l}\mathrm{NO} \\
\mathrm{NO}\end{array}$ & $\begin{array}{l}\text { YES } \\
\text { NO }\end{array}$ & $\begin{array}{l}\text { YES } \\
\text { YES }\end{array}$ \\
\hline Observations & $1,503,181$ & $1,503,181$ & $1,503,181$ \\
\hline R-squared & 0.263 & 0.272 & 0.275 \\
\hline $\operatorname{LR} \chi^{2}$ & 38269 & 33033 & 10552 \\
\hline $\operatorname{Prob}<\chi^{2}$ & 0.000 & 0.000 & 0.000 \\
\hline
\end{tabular}

Source: National Institute of Statistics. 
Table 7. GLS Estimation of Wages of Spain.

\begin{tabular}{|c|c|c|}
\hline & (1) & $(2)$ \\
\hline Age $(20-49$ years old $)$ & $\begin{array}{c}0.072^{* * *} \\
(0.004)\end{array}$ & $\begin{array}{c}0.071^{* * *} \\
(0.004)\end{array}$ \\
\hline Age (50-60 years old) & $\begin{array}{c}0.285^{* * *} * \\
(0.005)\end{array}$ & $\begin{array}{c}0.286^{* * *} * \\
(0.005)\end{array}$ \\
\hline Gender (Female) & $\begin{array}{c}-0.321 * * * \\
(0.002)\end{array}$ & $\begin{array}{c}-0.321^{* * *} \\
(0.002)\end{array}$ \\
\hline Education (Tertiary) & $\begin{array}{c}0.476^{* * *} \\
(0.003)\end{array}$ & $\begin{array}{c}0.470^{* * *} \\
(0.003)\end{array}$ \\
\hline Low-Tech Industry & $\begin{array}{c}0.177^{* * *} \\
(0.003)\end{array}$ & $\begin{array}{c}0.173^{* * *} * \\
(0.003)\end{array}$ \\
\hline High-Tech Industry & & \\
\hline Skilled Market Services & $\begin{array}{l}-0.003 \\
(0.003)\end{array}$ & $\begin{array}{l}-0.004 \\
(0.003)\end{array}$ \\
\hline Skilled Non-Market Services & $\begin{array}{c}0.233^{* * *} * \\
(0.004)\end{array}$ & $\begin{array}{c}0.235^{* * *} * \\
(0.004)\end{array}$ \\
\hline Low-Tech Industry $*$ Education (Tertiary) & $\begin{array}{c}-0.104^{* * *} \\
(0.006)\end{array}$ & $\begin{array}{c}-0.103 * * * \\
(0.006)\end{array}$ \\
\hline High-Tech Industry $*$ Education (Tertiary) & $\begin{array}{l}-0.090^{* * *} \\
(0.008)\end{array}$ & $\begin{array}{c}-0.090^{* * *} \\
(0.008)\end{array}$ \\
\hline Skilled Market Services $*$ Education (Tertiary) & & $\begin{array}{c}0.199^{* * * *} \\
(0.006)\end{array}$ \\
\hline Skilled Non-Market Services $*$ Education (Tertiary) & $\begin{array}{l}-0.111^{* * *} * \\
(0.005)\end{array}$ & $\begin{array}{c}-0.111^{* * * *} \\
(0.005)\end{array}$ \\
\hline Constant & $\begin{array}{c}5.020 * * * \\
(0.004)\end{array}$ & $\begin{array}{c}5.049^{* * *} \\
(0.005)\end{array}$ \\
\hline $\begin{array}{l}\text { Geographic Controls } \\
\text { Time Fixed Effects }\end{array}$ & $\begin{array}{l}\mathrm{NO} \\
\mathrm{NO}\end{array}$ & $\begin{array}{l}\text { NO } \\
\text { YES }\end{array}$ \\
\hline $\begin{array}{l}\text { Observations } \\
\text { R-squared } \\
\text { LR } \chi^{2} \\
\text { Prob }<\chi^{2}\end{array}$ & $\begin{array}{c}426,205 \\
0.210 \\
9444 \\
0.000\end{array}$ & $\begin{array}{c}426,205 \\
0.212 \\
8807 \\
0.000 \\
\end{array}$ \\
\hline
\end{tabular}

Source: National Institute of Statistics.

Table 8. Existence of Directed Technical Change.

\begin{tabular}{lcccccc}
\hline \multicolumn{5}{c}{ U.S. South Korea France Canada } & Italy & Spain \\
\hline Macrodata Approach & YES & YES & YES & NO & Few observations & In High-Tech Industry \\
\hline Microdata Approach & YES & YES & YES & NO & $\underset{\text { Not seS }}{\text { YESificant }}$ & $\begin{array}{c}\text { YES } \\
\text { Few observations }\end{array}$ \\
\hline Conclusion & YES & YES & YES & NO & $\overline{\text { Lack of clear evidence Lack of clear evidence }}$ \\
\hline
\end{tabular}




\section{Conclusions}

An increase in skilled labor supply is common across countries, but the existence of directed technical change is crucial to allocate skilled workers to high TFP sectors and lead economies towards high income levels. We have faced two paths of structural change suggested in previous literature —skill-biased structural transformation and stagnant structural transformation - and we argue that if there is no directed technical change, skilled workers end up in low TFP sectors, as the path of stagnant structural transformation suggests. We have proposed an identification of directed technical change through the analysis of relative TFP between skilled and unskilled sectors and an estimation of wages. We present macrodata and microdata evidence for the U.S., South Korea, France, Canada, Italy, and Spain. With the macrodata evidence, we identify that an increasing relative TFP of skilled versus unskilled sectors suggests that there is directed technical change in the U.S., France and South Korea. This finding is supported at micro level through a GLS estimation of wages, in which the coefficients of the interaction term between tertiary education and high TFP sectors are the highest and significant. This behavior is also found in the U.S., France and South Korea. Canada has not experienced directed technical change yet, and we cannot draw any definite conclusions about the existence of directed technical change in Italy and Spain. Directed technical change can lead to a reduction of the gap in GDP per capita among countries - relative to the U.S.as observed in the case of South Korea. 


\section{Bibliography}

Acemoglu, D. (1998). Why Do New Technologies Complement Skills? Directed Technical Change and Wage Inequality. Quarterly Journal of Economics, 113(4):1055-1089.

Acemoglu, D. (2002). Directed Technical Change. Review of Economic Studies, 69(4):781809.

Acemoglu, D. (2003). Patterns of Skill Premia. Review of Economic Studies, 70(2):199230.

Acemoglu, D. and Autor, D. (2011). Skills, Tasks and Technologies: Implications for Employment and Earnings. In Card, D. and Ashenfelter, O., editors, Handbook of Labor Economics, volume 4, chapter 12, pages 1043-1171. Amsterdam: Elsevier-North Holland.

Autor, D. H. and Dorn, D. (2013). The Growth of Low-Skill Service Jobs and the Polarization of the US Labor Market. The American Economic Review, 103(5):1553-1597.

Bahar, D. and Santos, M. (2018). One More Resource Curse: Dutch Disease and Export Concentration. Journal of Development Economics, 132(C):102-114.

Bandyopadhyay, D., King, I., and Tang, X. (2019). Human Capital Misallocation, Redistributive Policies, and TFP. Journal of Macroeconomics, 60(C):309-324.

Barany, Z. L. and Siegel, C. (2017). Job Polarization and Structural Change. American Economic Journal: Macroeconomics, 10(1):57-89.

Baumol, W. J. (1967). Macroeconomics of Unbalanced Growth: The Anatomy of Urban Crisis. The American Economic Review, 57(3):415-426.

Boppart, T. (2014). Structural Change and the Kaldor Facts in a Growth Model With Relative Price Effects and Non-Gorman Preferences. Econometrica, 82(6):2167-2196. Buera, F. J. and Kaboski, J. P. (2009). Can Traditional Theories of Structural Change Fit the Data? Journal of the European Economic Association, 7(2-3):469-477.

Buera, F. J. and Kaboski, J. P. (2012). The Rise of the Service Economy. American Economic Review, 102(6):2540-69. 
Buera, F. J., Kaboski, J. P., Rogerson, R., and Vizcaino, J. I. (2018). Skill Biased Structural Change. Working Paper 21165, National Bureau of Economic Research.

Cameron, A. and Trivedi, P. (2005). Microeconometrics, Methods and Applications. Cambridge University Press, 8 edition.

Caselli, F. and Coleman, W. J. (2001). The U.S. Structural Transformation and Regional Convergence: A Reinterpretation. Journal of Political Economy, 109(3):584-616.

Comin, D. A., Lashkari, D., and Mestieri, M. (2015). Structural Change with LongRun Income and Price Effects. Working Paper 21595, National Bureau of Economic Research.

Cruz, E. (2017). Structural Change and Non-Constant Biased Technical Change. The B.E. Journal of Macroeconomics, 17(2):1-23.

Cruz, E. (2019). Kuznets Meets Lucas: Structural Change and Human Capital. Oxford Economic Papers, 71(4):848-873.

Dix-Carneiro, R. (2014). Trade Liberalization and Labor Market Dynamics. Econometrica, 182(3):825-885.

Duarte, M. and Restuccia, D. (2010). The Role of the Structural Transformation in Aggregate Productivity. Quarterly Journal of Economics, 125(1):129-173.

Duernecker, G., Herrendorf, B., and Valentinyi, A. (2017). Structural Change within the Service Sector and the Future of Baumol's Disease. CEPR Discussion Papers 12467, C.E.P.R. Discussion Papers.

Foellmi, R. and Zweimüller, J. (2008). Structural Change, Engel's Consumption Cycles and Kaldor's Facts of Economic Growth. Journal of Monetary Economics, 55(7):13171328.

García-Santana, M., Pijoan-Mas, J., and Villacorta, L. (2016). Investment Demand and Structural Change. CEPR Discussion Paper DP11636.

Goldin, C. and Katz, L. F. (1998). The Origins of Technology-Skill Complementarity. Quarterly Journal of Economics, 113(3):693-732. 
Gollin, D., Lagakos, D., and Waugh, M. E. (2013). The Agricultural Productivity Gap. Quarterly Journal of Economics, 129(2):939-993.

Herrendorf, B., Rogerson, R., and Ákos Valentinyi (2014). Growth and Structural Transformation. In Aghion, P. and Durlauf, S. N., editors, Handbook of Economic Growth, volume 2, chapter 6, pages 855-941. Amsterdam: Elsevier-North Holland.

Herrendorf, B. and Schoellman, T. (2018). Wages, Human Capital, and Barriers to Structural Transformation. American Economic Journal: Macroeconomics, 10(2):123.

Hsieh, C.-T. (2002). What Explains the Industrial Revolution in East Asia? Evidence from the Factor Markets. The American Economic Review, 92(3):502-526.

Jorgenson, D. W. and Timmer, M. P. (2011). Structural Change in Advanced Nations: A New Set of Stylised Facts. Journal of Economics, 113(1):1-29.

Kaboski, J. P. (2009). Education, Sectoral Composition, and Growth. Review of Economic Dynamics, 12(1):168-182.

Katz, L. F. and Murphy, K. M. (1992). Changes in Relative Wages, 1963-1987: Supply and Demand Factors*. The Quarterly Journal of Economics, 107(1):35-78.

Kongsamut, P., Rebelo, S., and Xie, D. (2001). Beyond Balanced Growth. Review of Economic Studies, 68(4):869-882.

Kuralbayeva, K. and Stefanski, R. (2013). Windfalls, Structural Transformation and Specialization. Journal of International Economics, 90(2):273-301.

Laitner, J. (2000). Structural Change and Economic Growth. The Review of Economic Studies, 67(3):545-561.

Lee, D. and Wolpin, K. I. (2006). Intersectoral Labor Mobility and the Growth of the Service Sector. Econometrica, 74(1):1-46.

Lucas, R. E. (1978). On the Size Distribution of Business Firms. The Bell Journal of Economics, 9(2):508-523.

Minnesota, P. C. (2019). Integrated Public Use Microdata Series, International: Version 7.2 [dataset]. Minneapolis, MN: IPUMS, 2019. https ://doi .org/10.18128/D020.V7. 
Ngai, L. and Pissarides, C. (2007). Structural Change in a Multisector Model of Growth. The American Economic Review, 97(1):429-443.

Rogerson, R. (2008). Structural Transformation and the Deterioration of European Labor Market Outcomes. Journal of Political Economy, 116(2):235-259.

Romer, P. M. (1990). Endogenous Technological Change. Journal of Political Economy, 98(5):S71-S102.

Schoellman, T. (2011). Education Quality and Development Accounting. Review of Economic Studies, 79(1):388-417.

Stefanski, R. (2014). Structural Transformation and the Oil Price. Review of Economic Dynamics, 17(3):484-504.

Święcki, T. (2017). Determinants of Structural Change. Review of Economic Dynamics, 24:95-131.

Timmer, M. P. and de Vries, G. J. (2009). Structural Change and Growth Accelerations in Asia and Latin America: A New Sectoral Data Set. Cliometrica, 3(2):165-190.

Üngör, M. (2017). Productivity Growth and Labor Reallocation: Latin America versus East Asia. Review of Economic Dynamics, 24:25-42. 


\section{APPENDIX}

\section{Figures}

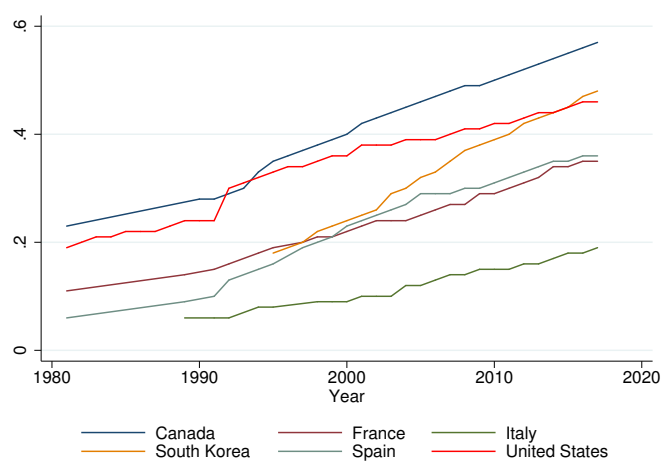

Fig. 11. Completed Tertiary Education. Source: OECD.

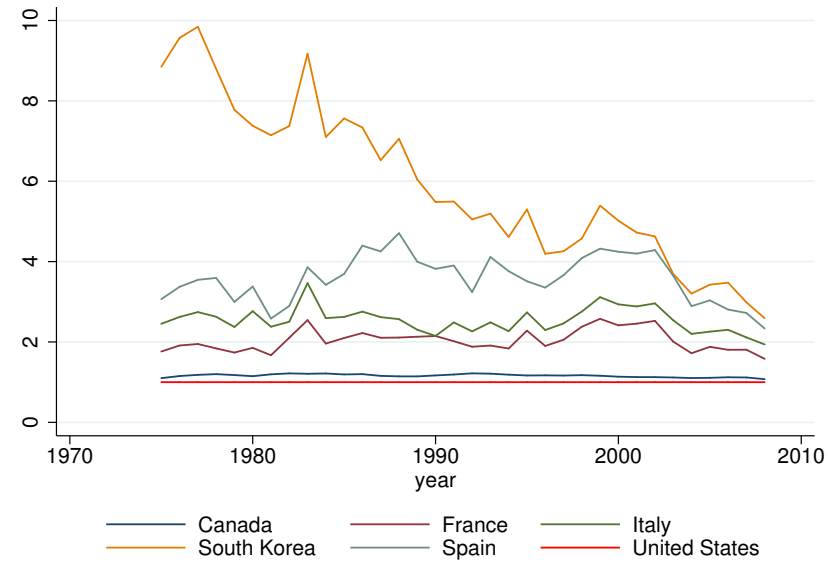

Fig. 12. Share of Value Added of Agriculture Compared to the U.S. Source: EU KLEMS and WORLD KLEMS Databases. 


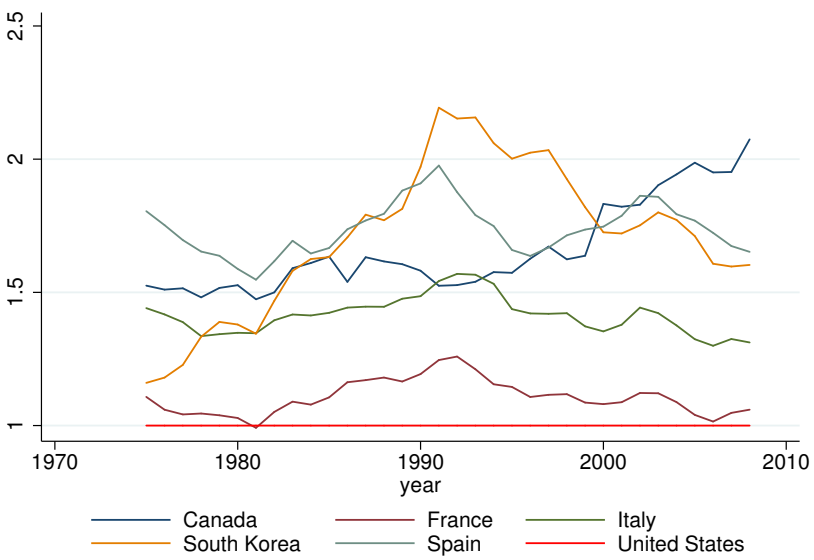

Fig. 13. Share of Value Added of Low-Tech Industry Compared to the U.S. Source: EU KLEMS and WORLD KLEMS Databases.

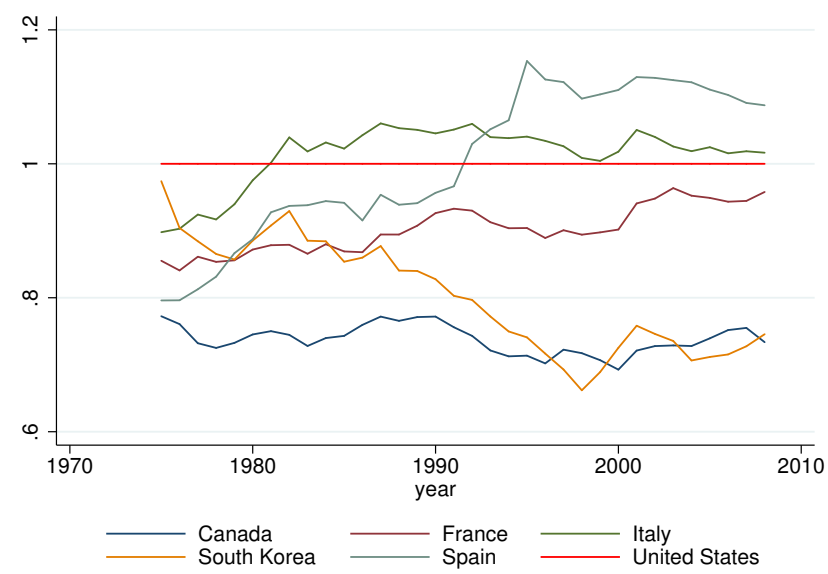

Fig. 14. Share of Value Added of Unskilled Services Compared to the U.S. Source: EU KLEMS and WORLD KLEMS Databases.

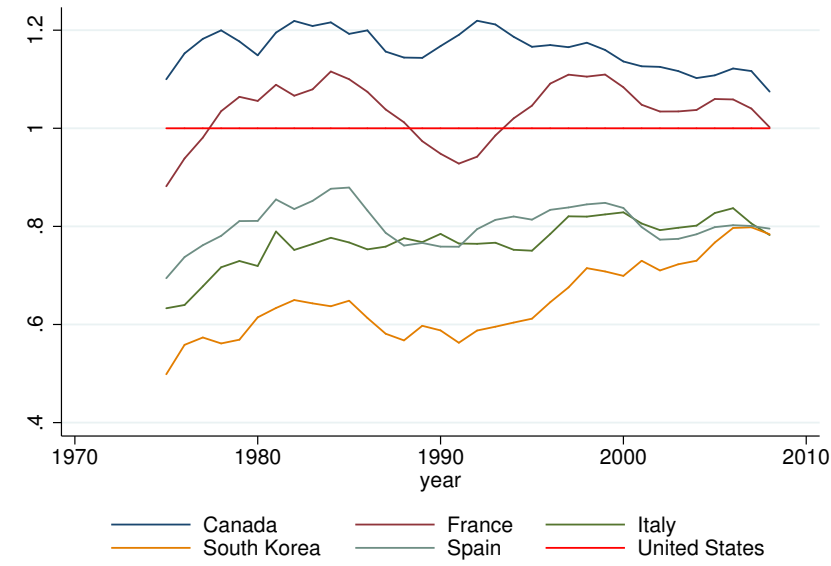

Fig. 15. Share of Value Added of Skilled Non-Market Services Compared to the U.S. Source: EU KLEMS and WORLD KLEMS Databases. 


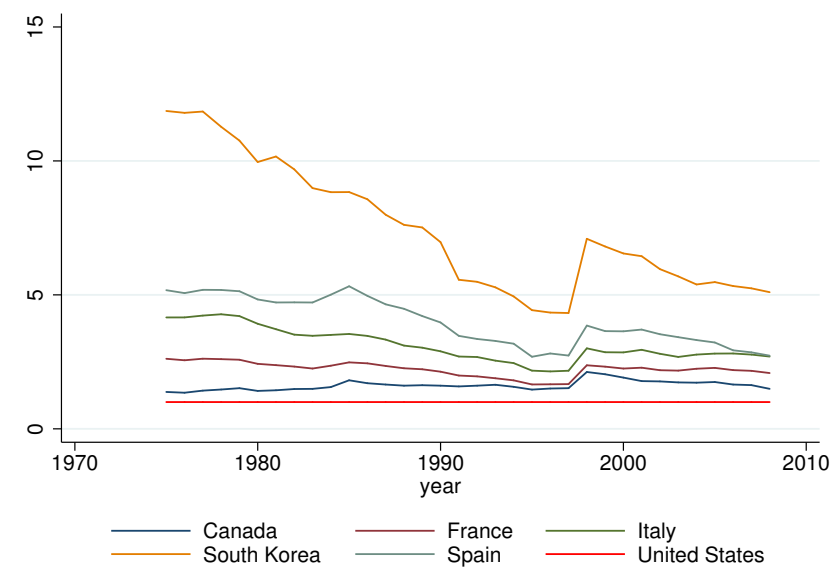

Fig. 16. Share of Labor of Agriculture Compared to the U.S. Source: EU KLEMS and WORLD KLEMS Databases.

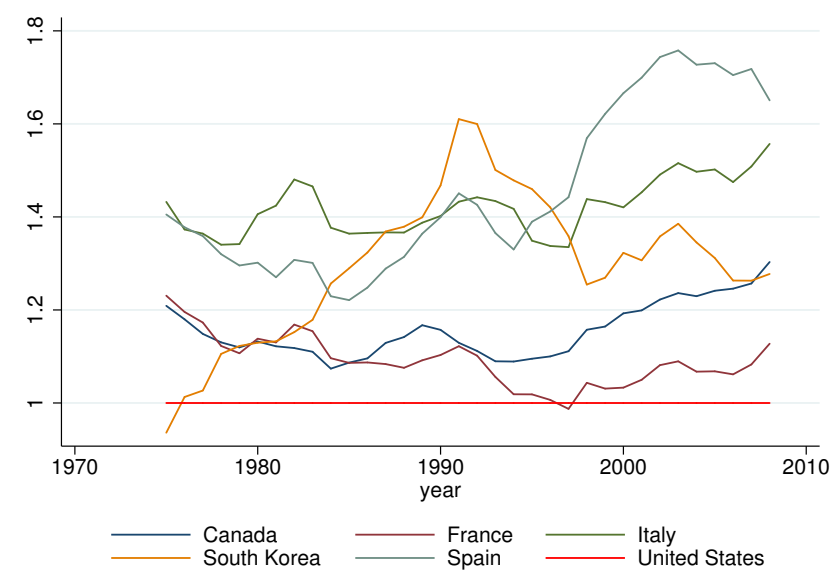

Fig. 17. Share of Labor of Low-Tech Industry Compared to the U.S. Source: EU KLEMS and WORLD KLEMS Databases.

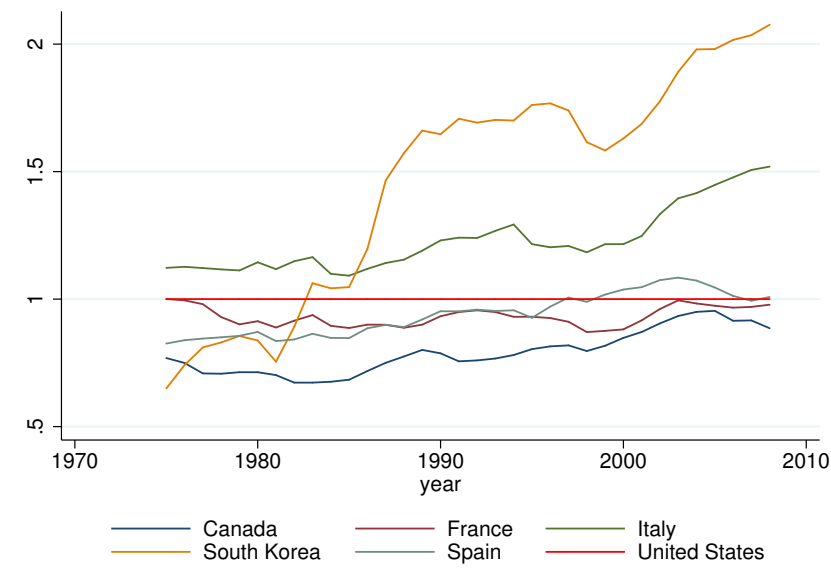

Fig. 18. Share of Labor of High-Tech Industry Compared to the U.S. Source: EU KLEMS and WORLD KLEMS Databases. 


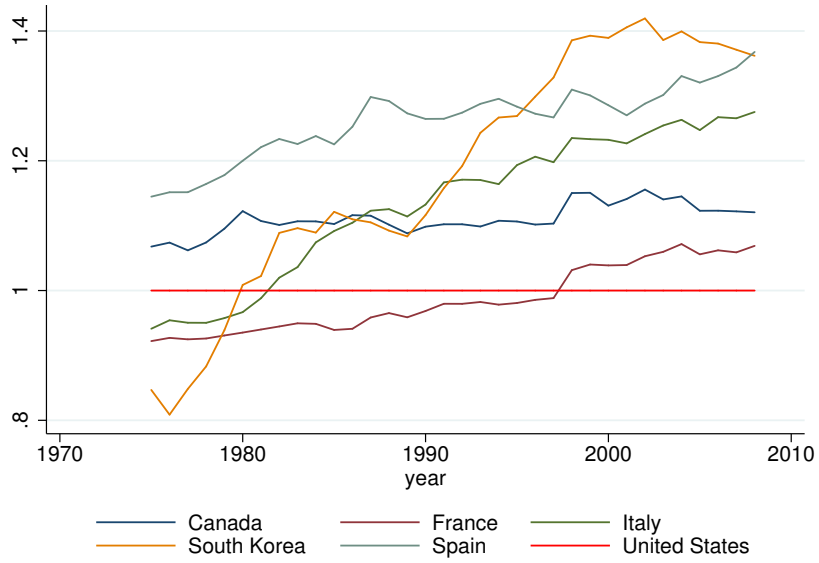

Fig. 19. Share of Labor of Unskilled Services Compared to the U.S. Source: EU KLEMS and WORLD KLEMS Databases.

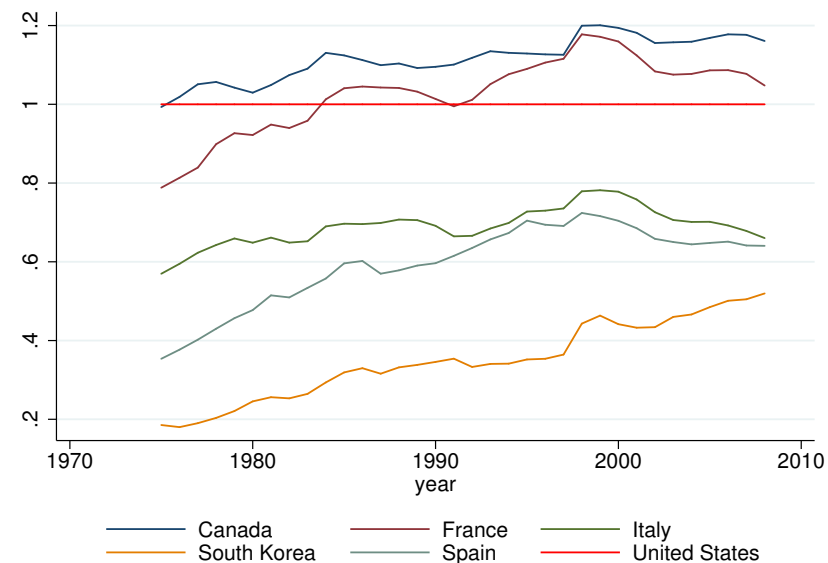

Fig. 20. Share of Labor of Skilled Non-Market Services Compared to the U.S. Source: EU KLEMS and WORLD KLEMS Databases. 


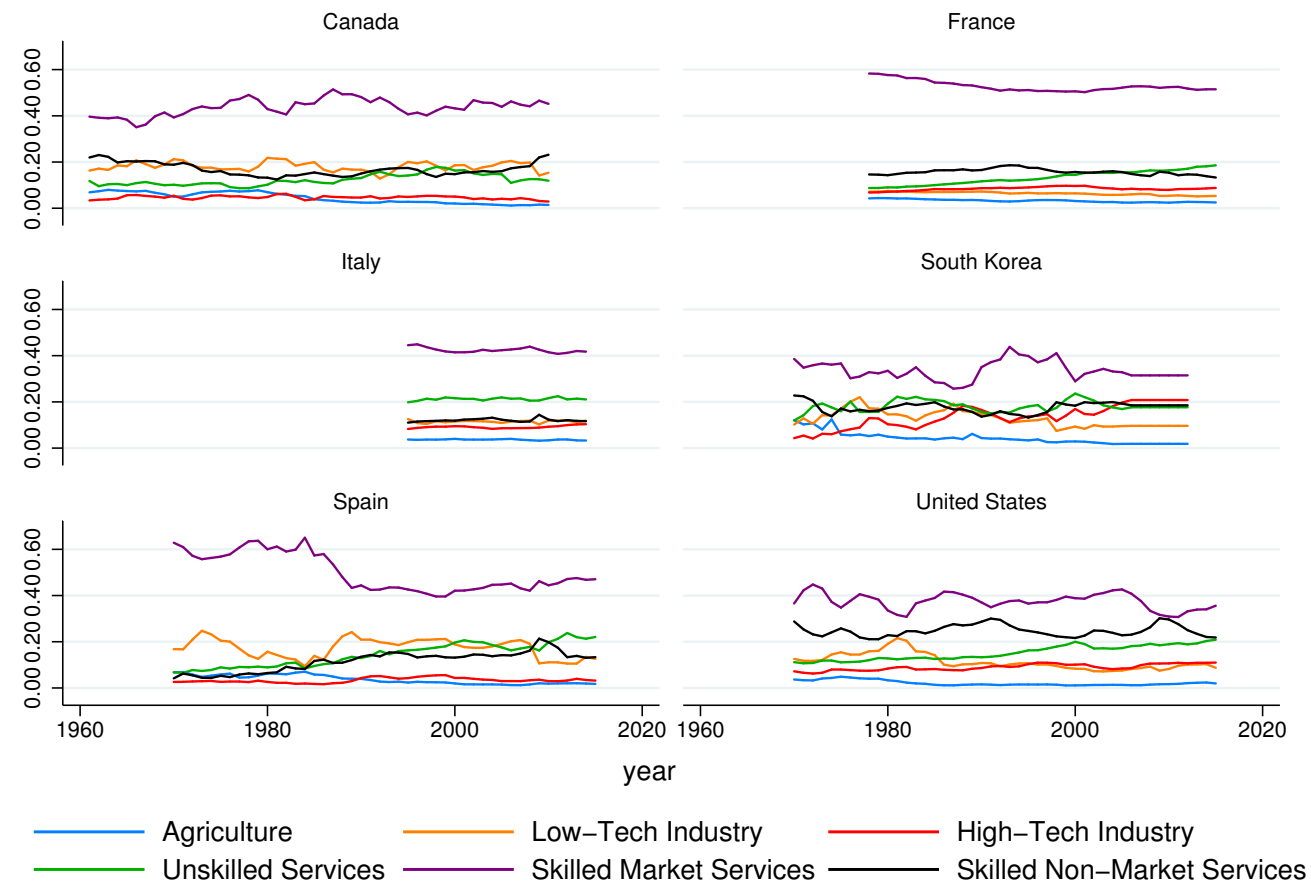

Fig. 21. Share of Capital

Source: EU KLEMS and WORLD KLEMS Databases.

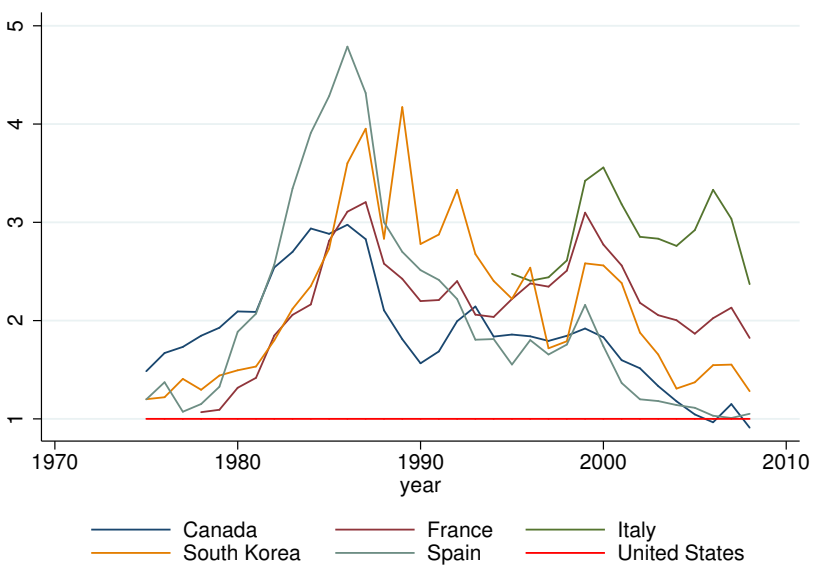

Fig. 22. Share of Capital of Agriculture Compared to the U.S. Source: EU KLEMS and WORLD KLEMS Databases. 


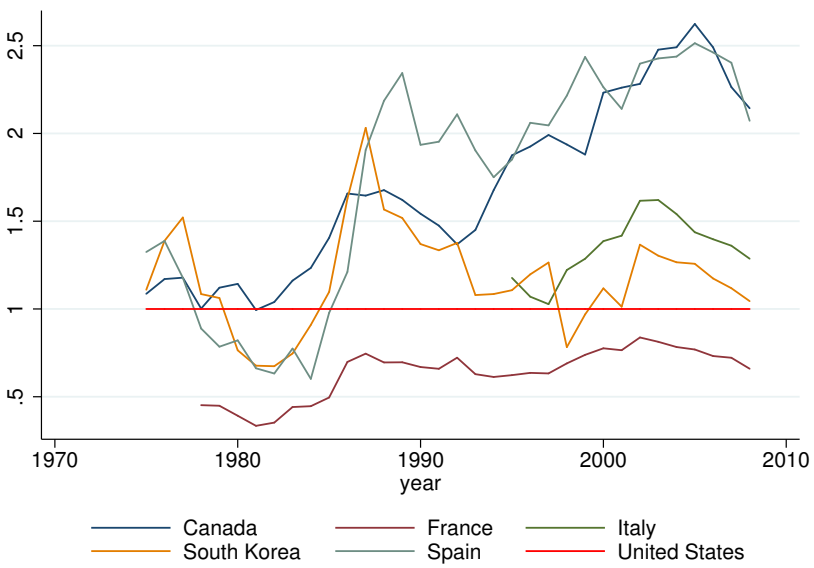

Fig. 23. Share of Capital of Low-Tech Industry Compared to the U.S. Source: EU KLEMS and WORLD KLEMS Databases.

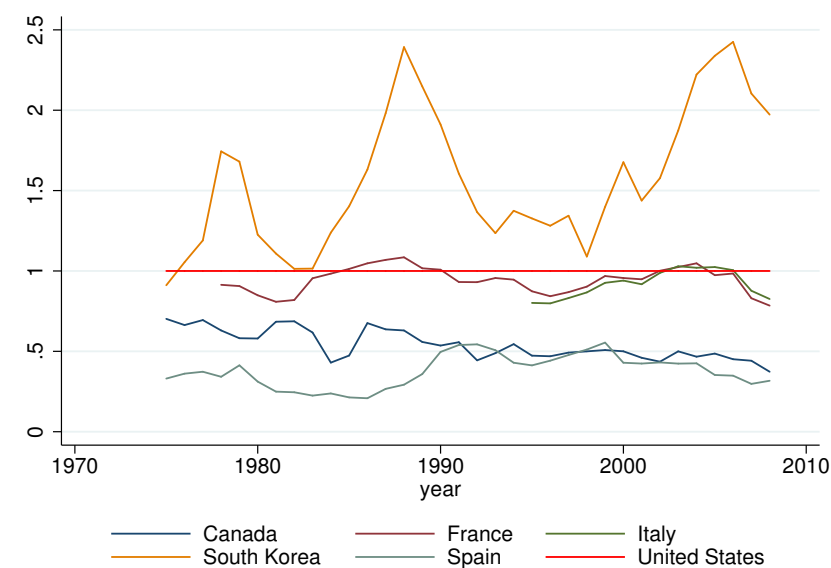

Fig. 24. Share of Capital of High-Tech Industry Compared to the U.S. Source: EU KLEMS and WORLD KLEMS Databases.

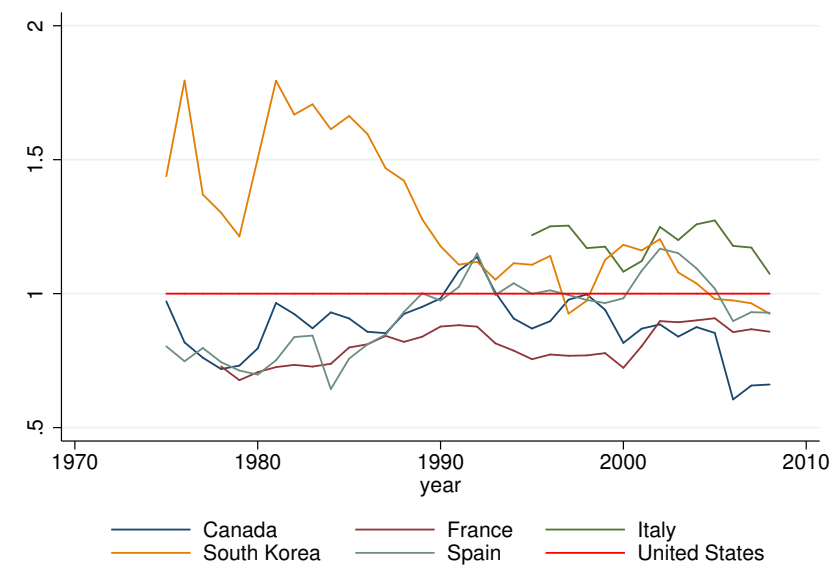

Fig. 25. Share of Capital of Unskilled Services Compared to the U.S. Source: EU KLEMS and WORLD KLEMS Databases. 


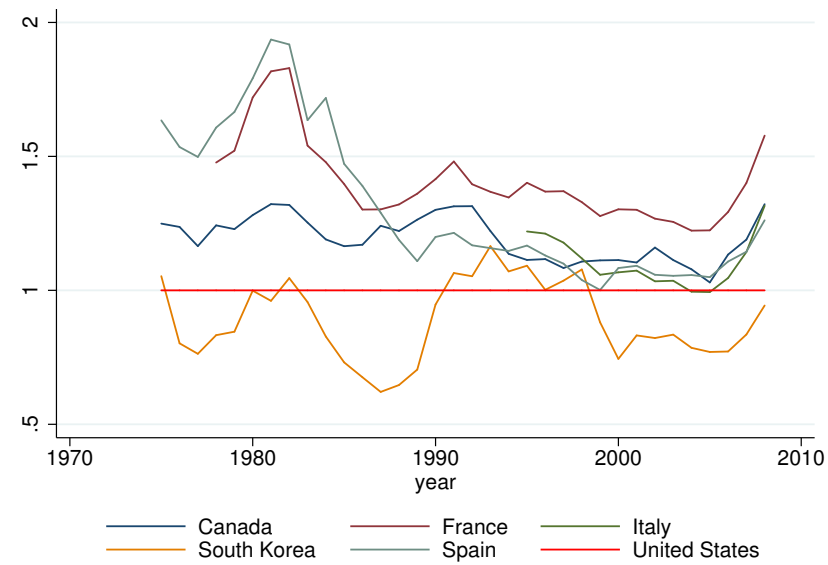

Fig. 26. Share of Capital of Skilled Market Compared to the U.S. Source: EU KLEMS and WORLD KLEMS Databases.

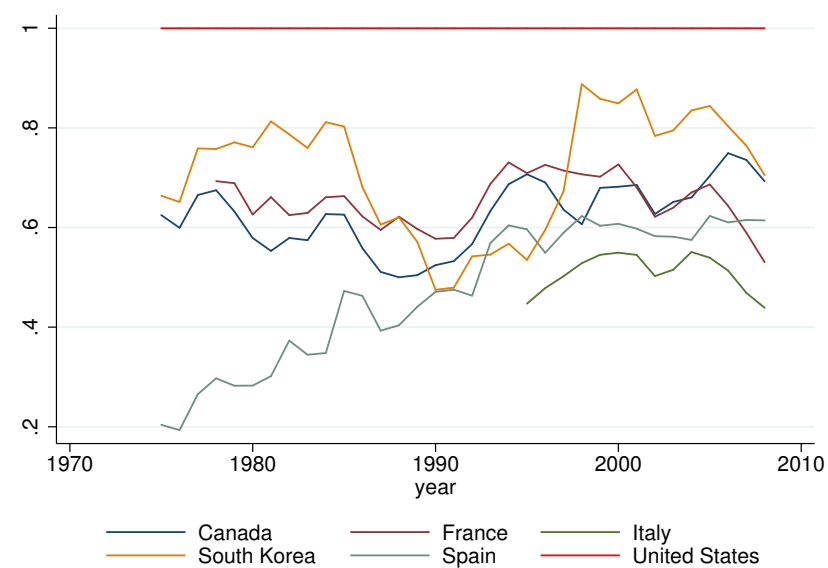

Fig. 27. Share of Capital of Skilled Non-Market Services Compared to the U.S. Source: EU KLEMS and WORLD KLEMS Databases. 


\section{Tables}

Table 9. Linear Regression of the Share of Value Added of Skilled Sectors and the Share of Completed Tertiary Educated Population

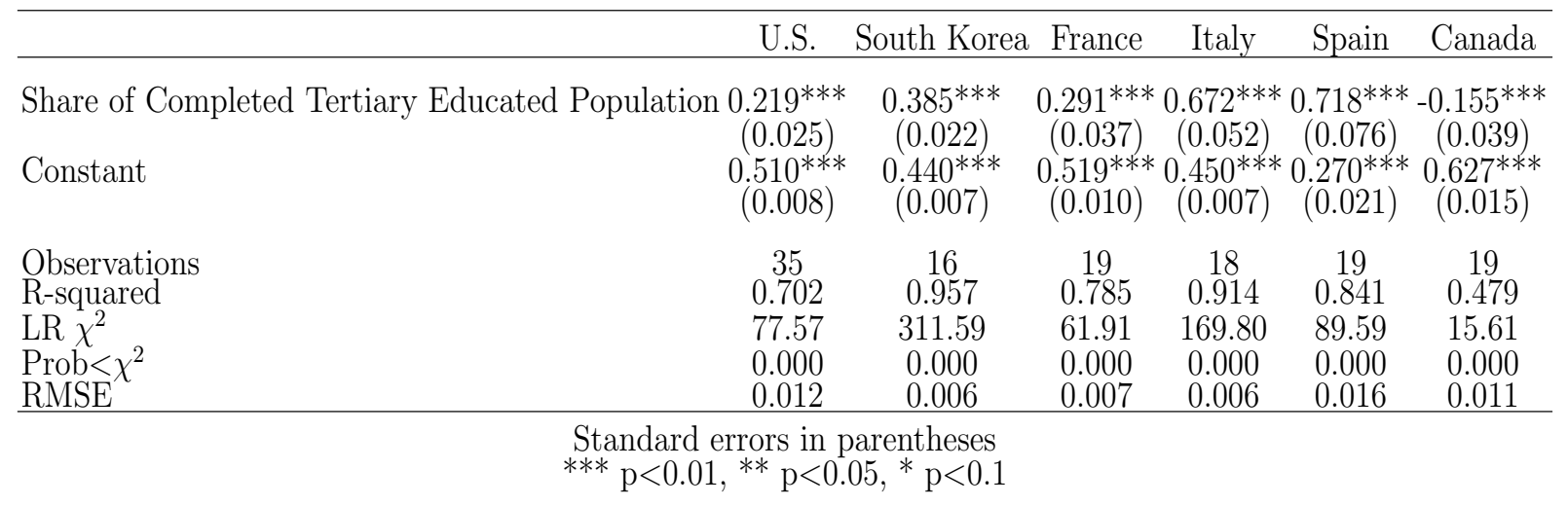

Source: EU KLEMS, KLEMS and OECD.

Table 10. Linear Regression of the Share of Value Added of Unskilled Sectors and the Share of Completed Tertiary Educated Population

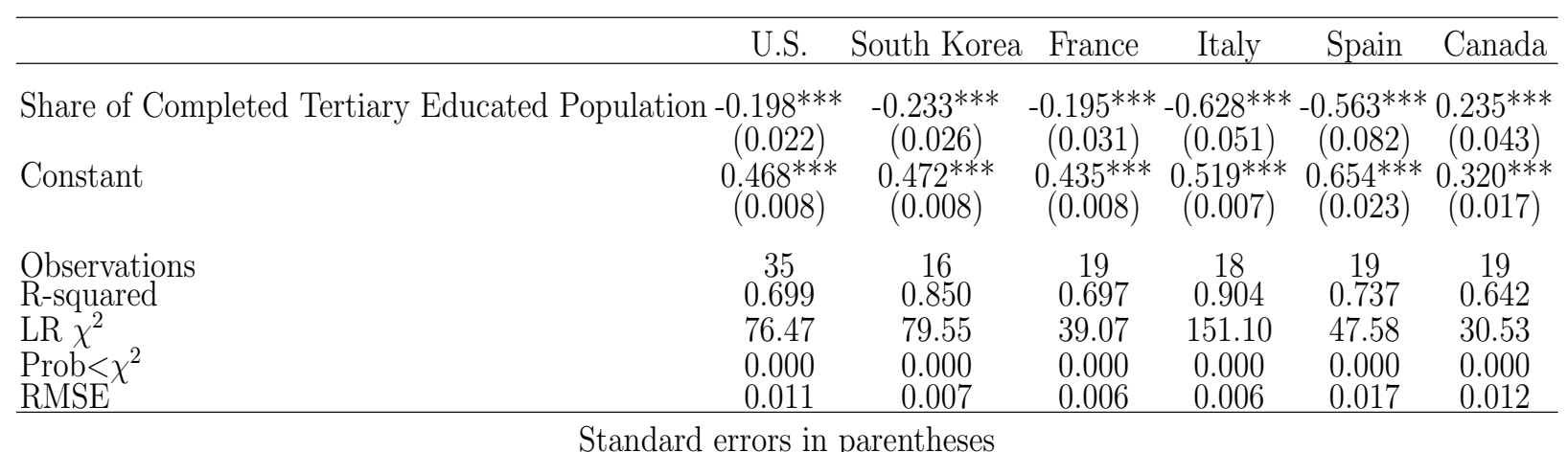

Standard errors in parentheses

Source: EU KLEMS, KLEMS and OECD. 
Table 11. GLS Estimation of Wages of U.S.

\begin{tabular}{|c|c|}
\hline VARIABLES & ln_wage \\
\hline Age & $0.132^{* * *}$ \\
\hline $\mathrm{Age}^{2}$ & $\begin{array}{c}-0.001^{* * *} \\
(0.000)\end{array}$ \\
\hline Gender (Female) & $\begin{array}{c}-0.422^{* * *} \\
(0.000)\end{array}$ \\
\hline Education (Tertiary) & $\begin{array}{c}0.607^{* * *} * \\
(0.004)\end{array}$ \\
\hline Low-Tech Industry & $\begin{array}{c}0.423^{* * *} \\
(0.001)\end{array}$ \\
\hline High-Tech Industry & $\begin{array}{c}0.591^{* * *} \\
(0.001)\end{array}$ \\
\hline Unskilled Services & $\begin{array}{c}0.242^{* * *} * \\
(0.001)\end{array}$ \\
\hline Skilled Market Services & $\begin{array}{c}0.469^{* * *} * \\
(0.001)\end{array}$ \\
\hline Skilled Non-Market Services & $\begin{array}{c}0.382^{* * *} * \\
(0.001)\end{array}$ \\
\hline Low-Tech Industry $*$ Education (Tertiary) & $\begin{array}{c}-0.025^{* * *} \\
(0.004)\end{array}$ \\
\hline High-Tech Industry $*$ Education (Tertiary) & $\begin{array}{c}0.063^{* * *} * \\
(0.004)\end{array}$ \\
\hline Unskilled Services $*$ Education (Tertiary) & $\begin{array}{c}-0.065^{* * * *} \\
(0.004)\end{array}$ \\
\hline Skilled Market Services $*$ Education (Tertiary) & $\begin{array}{c}0.063 * * * \\
(0.004)\end{array}$ \\
\hline Skilled Non-Market Services $*$ Education (Tertiary) & $\begin{array}{c}-0.118^{* * *} \\
(0.004)\end{array}$ \\
\hline Region 1 & $\begin{array}{c}0.056^{* * *} \\
(0.000)\end{array}$ \\
\hline Region 2 & $\begin{array}{l}-0.021^{* * * *} \\
(0.000)\end{array}$ \\
\hline Region 3 & $\begin{array}{c}0.044^{* * * *} \\
(0.000)\end{array}$ \\
\hline Constant & $\begin{array}{c}4.710^{* * *} \\
(0.002)\end{array}$ \\
\hline $\begin{array}{l}\text { Observations } \\
\text { R-squared } \\
\text { LR } \chi^{2} \\
\text { Prob }<\chi^{2}\end{array}$ & $\begin{array}{c}21,557,941 \\
0.853 \\
5.192 \mathrm{e}+06 \\
0.000\end{array}$ \\
\hline
\end{tabular}

Source: IPUMS International. 
Table 12. GLS Estimation of Wages of South Korea

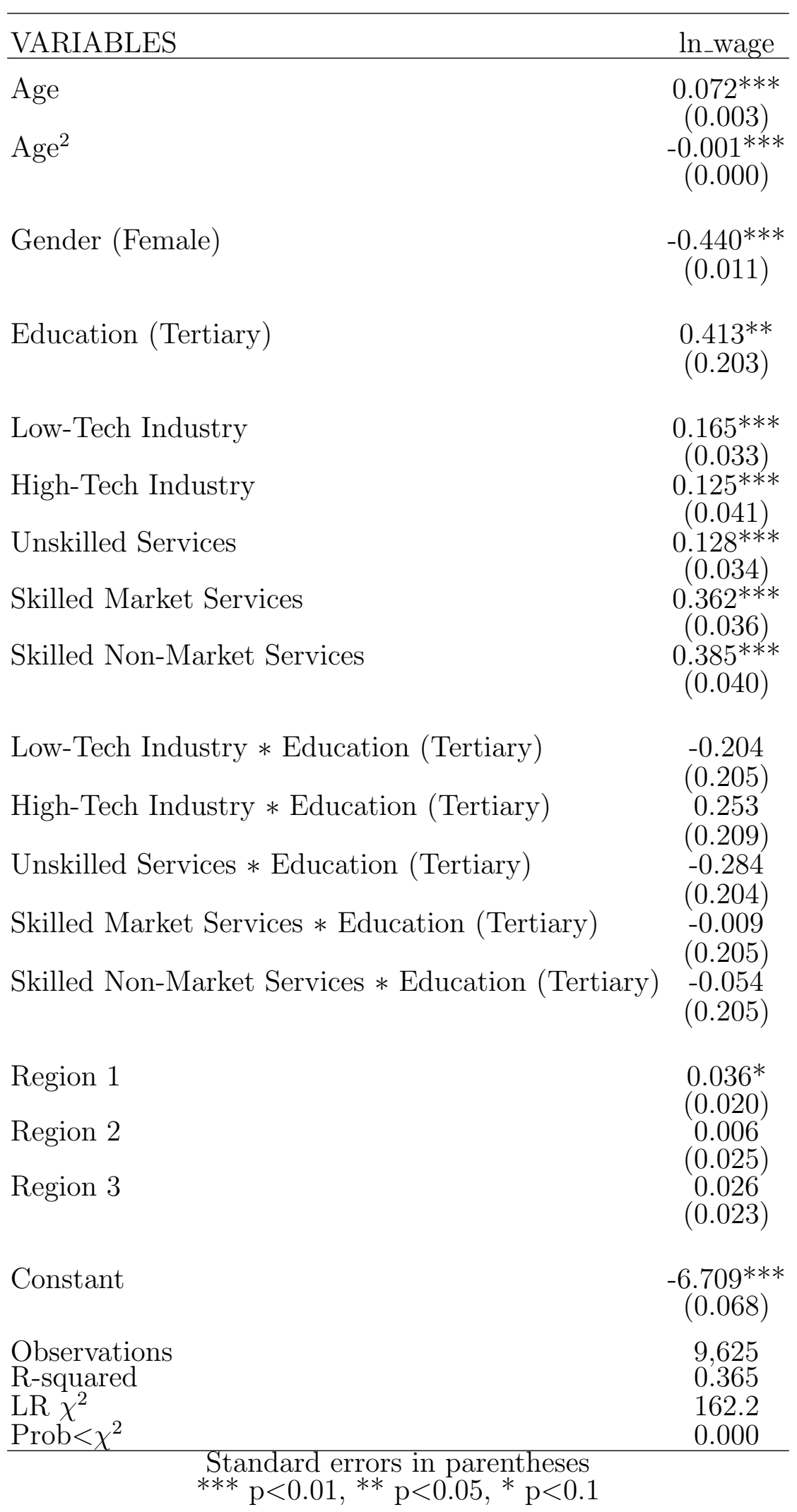

Source: Korea Labor Institute. 
Table 13. GLS Estimation of Wages of France

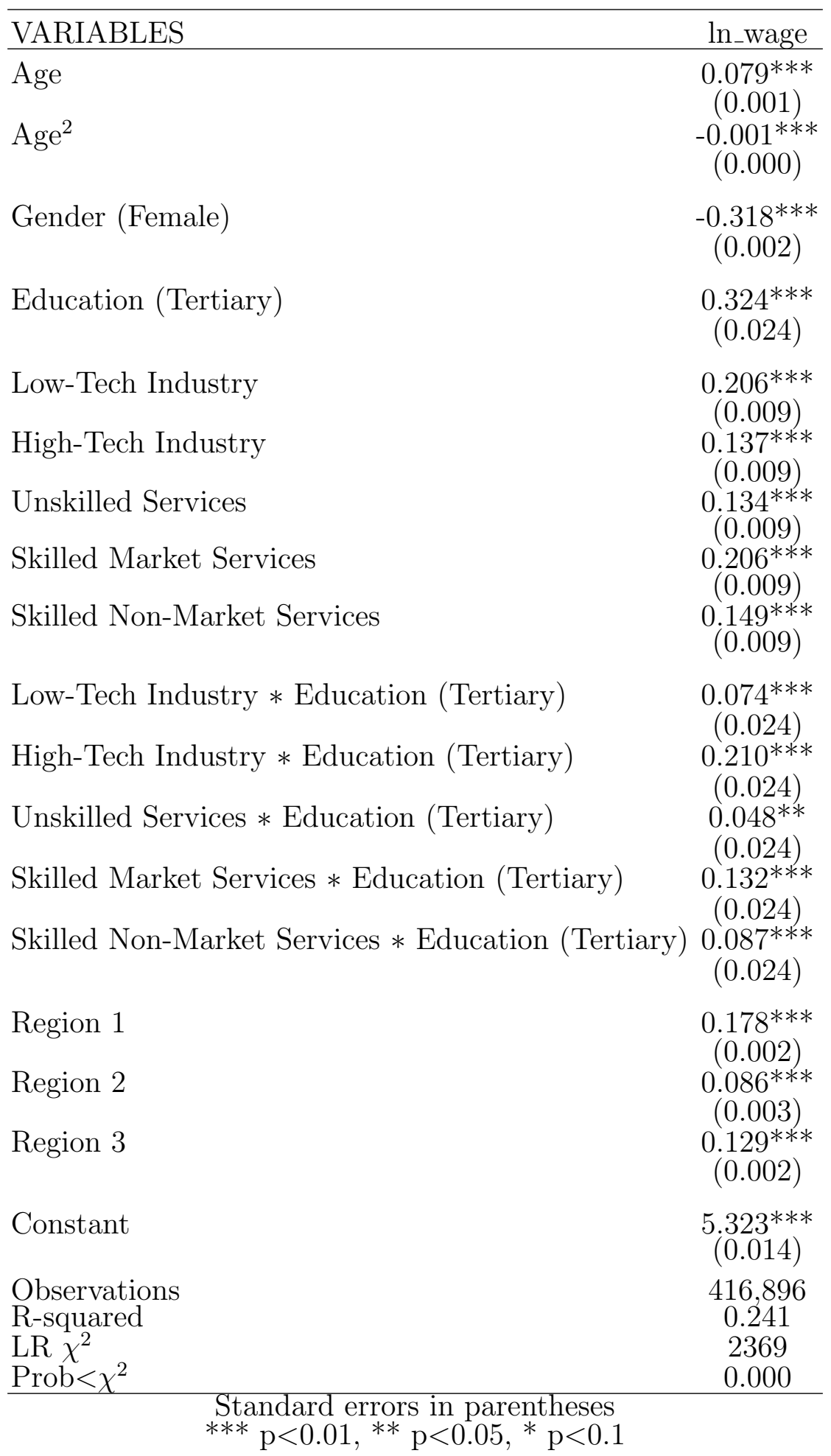

Source: National Institute of Statistics and Economic Studies. 
Table 14. GLS Estimation of Wages of Canada

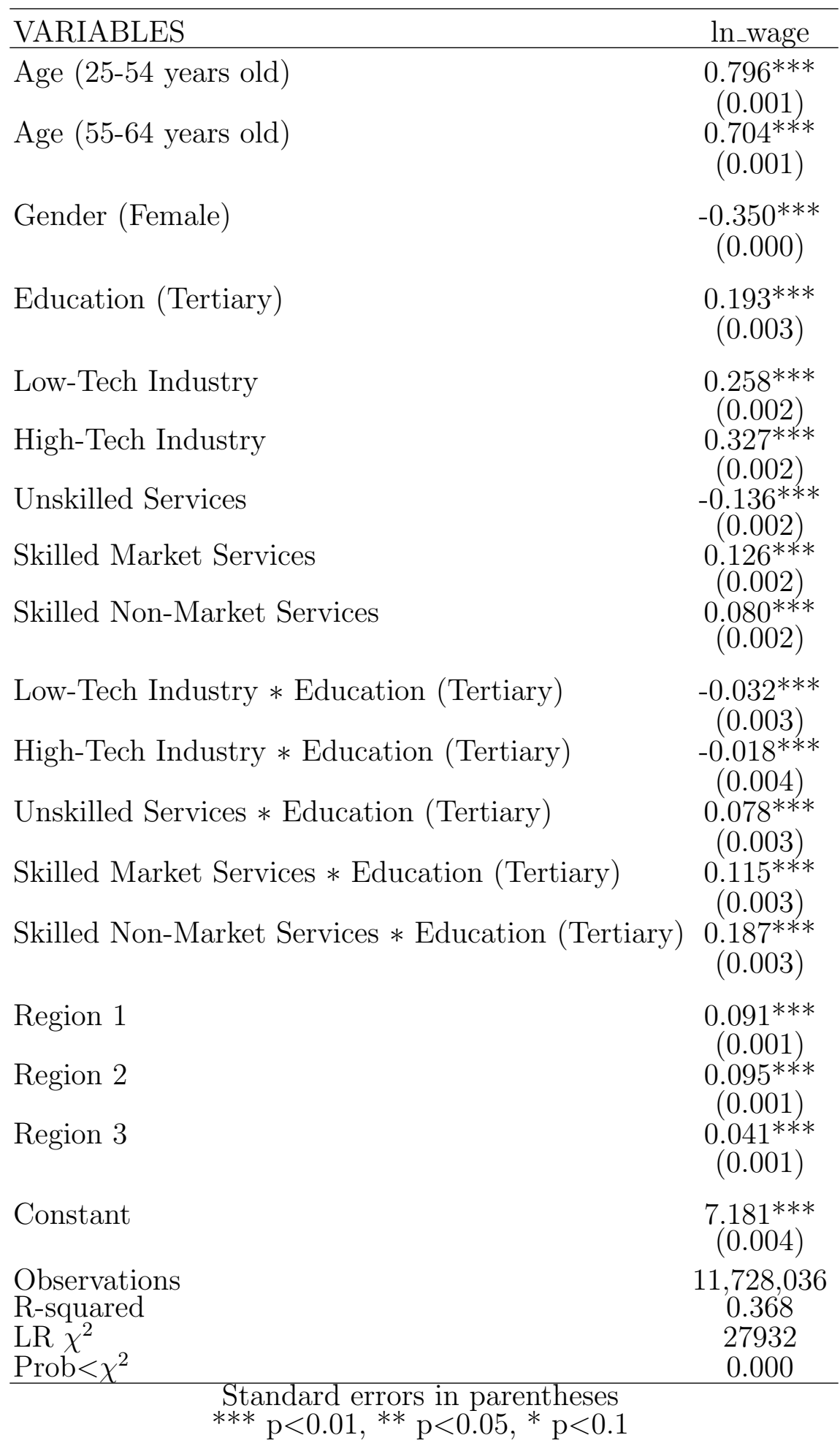

Source: Statistics Canada. 
Table 15. GLS Estimation of Wages of Italy

\begin{tabular}{|c|c|}
\hline VARIABLES & ln_wage \\
\hline Age & $0.038 * * *$ \\
\hline $\operatorname{Age}^{2}$ & $\begin{array}{c}-0.000^{* * *} \\
(0.000)\end{array}$ \\
\hline Gender (Female) & $\begin{array}{c}-0.290^{* * *} \\
(0.001)\end{array}$ \\
\hline Education (Tertiary) & $\begin{array}{c}0.338^{* * *} \\
(0.012)\end{array}$ \\
\hline Low-Tech Industry & $\begin{array}{c}0.313^{* * *} \\
(0.002)\end{array}$ \\
\hline High-Tech Industry & $\begin{array}{c}0.384^{* * *} * \\
(0.002)\end{array}$ \\
\hline Unskilled Services & $\begin{array}{l}0.203^{* * *} * \\
(0.002)\end{array}$ \\
\hline Skilled Market Services & $\begin{array}{c}0.283^{* * *} * \\
(0.002)\end{array}$ \\
\hline Skilled Non-Market Services & $\begin{array}{c}0.408^{* * *} * \\
(0.002)\end{array}$ \\
\hline Low-Tech Industry $*$ Education (Tertiary) & $\begin{array}{c}-0.036^{* * *} \\
(0.012)\end{array}$ \\
\hline High-Tech Industry $*$ Education (Tertiary) & $-0.021^{*}$ \\
\hline Unskilled Services $*$ Education (Tertiary) & $\begin{array}{c}-0.102^{* * * *} \\
(0.012)\end{array}$ \\
\hline Skilled Market Services $*$ Education (Tertiary) & \\
\hline Skilled Non-Market Services $*$ Education (Tertiary) & $\begin{array}{c}-0.091^{* * * *} \\
(0.012)\end{array}$ \\
\hline Region 1 & $\begin{array}{c}0.008 * * * \\
(0.002)\end{array}$ \\
\hline Region 2 & $\begin{array}{c}-0.020^{* * * *} \\
(0.002)\end{array}$ \\
\hline Region 3 & $\begin{array}{c}0.078^{* * * *} \\
(0.001)\end{array}$ \\
\hline Constant & $\begin{array}{c}5.928^{* * *} * \\
(0.005)\end{array}$ \\
\hline Observations & $1,503,181$ \\
\hline $\begin{array}{l}\text { R-squared } \\
L R \gamma^{2}\end{array}$ & $\begin{array}{l}0.275 \\
10552\end{array}$ \\
\hline $\begin{array}{l}\operatorname{Ln} \chi \\
\text { Prob }<\chi^{2}\end{array}$ & 0.000 \\
\hline
\end{tabular}

Source: National Institute of Statistics. 